\title{
Functional ACE2 deficiency leading to angiotensin imbalance in the pathophysiology of COVID-19
}

\author{
Joshua R. Cook ${ }^{1}$ (D) . John Ausiello ${ }^{1}$ (D) \\ Accepted: 4 June 2021 / Published online: 1 July 2021 \\ ( ) The Author(s), under exclusive licence to Springer Science+Business Media, LLC, part of Springer Nature 2021
}

\begin{abstract}
SARS-CoV-2, the virus responsible for COVID-19, uses angiotensin converting enzyme 2 (ACE2) as its primary cell-surface receptor. ACE2 is a key enzyme in the counter-regulatory pathway of the broader renin-angiotensin system (RAS) that has been implicated in a broad array of human pathology. The RAS is composed of two competing pathways that work in opposition to each other: the "conventional" arm involving angiotensin converting enzyme (ACE) generating angiotensin-2 and the more recently identified ACE2 pathway that generates angiotensin (1-7). Following the original SARS pandemic, additional studies suggested that coronaviral binding to ACE2 resulted in downregulation of the membrane-bound enzyme. Given the similarities between the two viruses, many have posited a similar process with SARS-CoV-2. Proponents of this ACE2 deficiency model argue that downregulation of ACE2 limits its enzymatic function, thereby skewing the delicate balance between the two competing arms of the RAS. In this review we critically examine this model. The available data remain incomplete but are consistent with the possibility that the broad multisystem dysfunction of COVID-19 is due in large part to functional ACE2 deficiency leading to angiotensin imbalance with consequent immune dysregulation and endothelial cell dysfunction.
\end{abstract}

Keywords Renin angiotensin system · Angiotensin converting enzyme · Angiotensin converting enzyme $2 \cdot$ Angiotensin- 2 . Angiotensin 1-7

\begin{tabular}{|c|c|}
\hline \multicolumn{2}{|c|}{ Abbreviations } \\
\hline SARS-CoV-1 & $\begin{array}{l}\text { Severe Acute Respiratory Syn- } \\
\text { drome Coronavirus } 1\end{array}$ \\
\hline SARS-CoV-2 & $\begin{array}{l}\text { Severe Acute Respiratory Syn- } \\
\text { drome Coronavirus } 2\end{array}$ \\
\hline RAS & Renin Angiotensin System \\
\hline AT1 & Angiotensin-1 \\
\hline AT2 & Angiotensin-2 \\
\hline $\mathrm{AT}(1-7)$ & Angiotensin (1-7) \\
\hline AT(1-9) & Angiotensin (1-9) \\
\hline $\mathrm{ACE}$ & $\begin{array}{l}\text { Angiotensin Converting } \\
\text { Enzyme }\end{array}$ \\
\hline ACE2 & $\begin{array}{l}\text { Angiotensin Converting } \\
\text { Enzyme } 2\end{array}$ \\
\hline AT1R & Angiotensin-2 Receptor Type 1 \\
\hline AT2R & Angiotensin-2 Receptor Type 2 \\
\hline MasR & Mas Receptor \\
\hline \multicolumn{2}{|c|}{$\begin{array}{l}\triangle \text { John Ausiello } \\
\text { ja2395@cumc.columbia.edu }\end{array}$} \\
\hline \multicolumn{2}{|r|}{ ork, NY, U } \\
\hline
\end{tabular}

\section{ADAM17}

TMPRSS2

$\mathrm{BK}$

NRP-1

SR-B1

ACE Inhibitors (ACEIs)

ARBs

\section{Introduction}

In January 2020, the world first began to hear of a cluster of cases of adult respiratory distress syndrome (ARDS) in Wuhan, China, marking the beginning of the COVID-19 pandemic. Soon thereafter, scientists isolated the culprit, a novel coronavirus known as severe acute respiratory syndrome coronavirus 2 (SARS-CoV-2) and confirmed that it primarily uses the same cell receptor as severe acute respiratory syndrome coronavirus 1 (SARS-CoV-1): angiotensin converting enzyme 2 (ACE2) [1-3]. Since this discovery, 
there has been renewed interest in defining the role of ACE2 in normal physiology in attempts to elucidate its potential involvement in COVID-19 pathology. As a critical component of the ubiquitous renin-angiotensin system (RAS), ACE2 is primarily involved in maintaining homeostasis within an array of normal physiologic functions ([4-8]. Furthermore, it is directly involved in bradykinin metabolism and has numerous non-catalytic functions in the gut $[4,6,9]$. Following the SARS pandemic, studies primarily in animal models confirmed that SARS-CoV-1 binding to ACE2 led to downregulation of the membrane-bound enzyme [10-12]. Extrapolating from this experience, a growing number of authors have posited that SARS-CoV-2 also induces downregulation of this critical enzyme, creating a functional ACE2 deficiency [4, 13-15]. In this review we will dissect the merits of this hypothesis. As we will discuss, there is evidence to suggest initial upregulation of ACE2 in airway cells, likely triggered by interferon signaling [16-19]. At the same time, mounting evidence suggests that COVID19 phenocopies a functionally ACE2 deficient state. Taken together, these seemingly incongruous statements raise the distinct possibility that ACE2 deficiency occurs later in the disease course thereby driving the second, inflammatory phase of COVID-19 [20].

\section{Overview of the renin-angiotensin system}

The RAS is complex and incompletely understood, comprising two "arms" with both tissue-level and systemic components [4-8]. Historically, our understanding of the RAS has been limited to the angiotensin converting enzyme (ACE)mediated pathway and its involvement in the regulation of intravascular volume. However, over the past two decades, a second, counterregulatory arm mediated by ACE2 has come into focus [4-8]. Given these additional complexities, it is now believed that the RAS is involved in an array of human physiology extending beyond its role in the maintenance of intravascular volume and that dysfunction of this system contributes to human disease, potentially including COVID19 [4-8, 13-15, 21, 22].

The traditional RAS pathway involves numerous key peptides and enzymes: angiotensinogen, angiotensin 1 (AT1), angiotensin 2 (AT2), renin, ACE, and aldosterone [6, 21] (Fig. 1). Angiotensinogen, an inactive precursor peptide, is cleaved by renin to form AT1, which in turn is processed by ACE to AT2. Angiotensin- 2 can be converted to angiotensin- 3 and -4 , but AT2 is considered the active signaling effector of the pathway [6, 21]. AT2 performs its multiple physiologic roles via signaling through two receptors: angiotensin- 2 receptor type $1\left(\mathrm{AT}_{1} \mathrm{R}\right)$ and angiotensin- 2 receptor type $2\left(\mathrm{AT}_{2} \mathrm{R}\right)[6,23,24]$. Of the two, activation of $\mathrm{AT}_{1} \mathrm{R}$ is better studied and thought to be the primary mediator of angiotensin-2's diverse biological effects [23]. Indeed, it is via $\mathrm{AT}_{1} \mathrm{R}$ that $\mathrm{AT} 2$ regulates aldosterone release from the adrenal cortex in response to changes in volume status [25]. In addition to its crucial role in fluid balance, AT2 activation of $\mathrm{AT}_{1} \mathrm{R}$ can promote vasoconstriction, angiogenesis, thrombosis, inflammation, and fibrosis [4, 23]. Interestingly, activation of $\mathrm{AT}_{2} \mathrm{R}$ may oppose the vascular actions of $\mathrm{AT}_{1} \mathrm{R}$ in certain contexts, but our understanding of this pathway is incomplete [23, 24].

Chymase, an endopeptidase primarily derived from mast cells, has also been shown to drive AT2 production $[6,26]$. This ACE-independent mechanism of angiotensin-2 generation likely plays an important role in certain pathologic processes $[6,26]$. In fact, in animal models there is a high level of compartmentalization between chymase and ACE [26]. Accumulating evidence indicates that chymase is the major regulator of tissue angiotensin-2 levels; in ACE-deficient mice, AT2 levels in the heart, lung, and kidneys are preserved despite undetectable levels in the circulation [26-28].

Although portrayed as a centralized mediator of systemic physiologic parameters, the spatial organization of the RAS is nested, featuring activities at the systemic, tissue, and cellular levels $[6,26,29,30]$. Moreover, its activities may be differentially regulated among various tissues or cell types. As such, its local components can act independently from the central pathway $[4-8,29,30]$. The latter point may be critical to any potential RAS involvement in COVID-19 as tissue angiotensin-2 levels can be significantly higher than systemic values within multiple organ systems $[6,26,31$, 32].

The critical components of the second arm of the RAS include ACE2, angiotensin (1-9) [AT(1-9)], and angiotensin (1-7) [AT(1-7)] [4-8, 33]. ACE2 is an ectoenzyme present in most human tissues that is primarily membrane-bound but may be cleaved by protease ADAM17 to produce soluble ACE2 (sACE2), a process ramped up in certain disease states $[4,33]$. ACE2 catalyzes the alternative conversion of AT1 to AT(1-9) - which subsequently is converted to AT(1-7) by a non-ACE2 mediated process - and of AT2 directly to AT(1-7) [33]. AT(1-7) likely binds to Mas receptors (MasR), promoting vasodilatory, anti-inflammatory, and anti-fibrotic effects $[4,23,33]$. Consequently, activation of this arm is thought to oppose the activity of the conventional ACE/AT2 pathway.

Secondarily, ACE2 acts in a non-catalytic fashion in the gut and participates in the enzymatic regulation of bradykinin (BK) signaling, which itself has been implicated in COVID-19 pathophysiology [4, 6, 9, 34]. ACE2 catabolizes bradykinin's active metabolite, des-Arg'-bradykinin, and thus ACE2 deficiency is expected to disinhibit bradykinin signaling [9]. A detailed analysis of BK's distinct impact on COVID-19 is beyond the scope of this review; however, given its role in vasodilation, inflammation, and vascular 


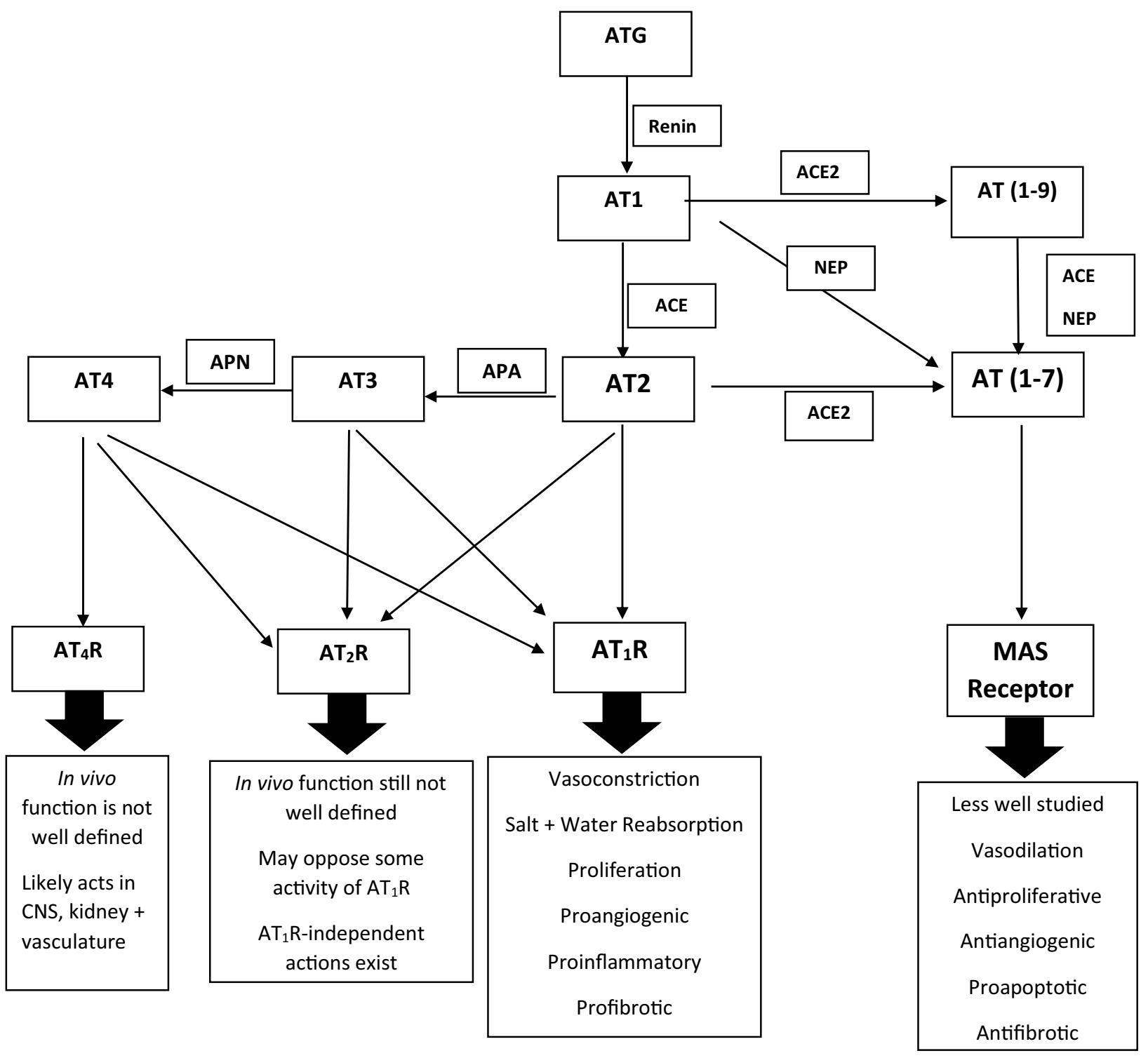

Abbreviations: ATG (angiotensinogen), AT1 (angiotensin 1), AT2 (angiotensin 2), AT (1-9) (angiotensin 1-9), AT (1-7) (angiotensin 1-7), AT3 (angiotensin 3), AT4 (angiotensin 4), ACE (angiotensin converting enzyme), ACE2 (angiotensin converting enzyme 2), NEP (neprilysin), APA (aminopeptidase A), APN (aminopeptidase N), AT ${ }_{1} R$ (angiotensin 2 receptor type 1 ), $A T_{2} R$ (angiotensin 2 receptor type 2 ), $A T_{4} R$ (angiotensin 2 receptor type 4 )

Fig. 1 An overview of the renin angiotensin system pathways

permeability, it is plausible that bradykinin dysregulation contributes to the overall clinical picture of ACE2 deficiency [34]. Additionally, BK likely increases chymase activity, providing additional avenues for AT2 production [35].

Under normal circumstances it is thought that the two arms of the RAS are balanced such that that an increase in ACE and AT2 is countered by a coordinate increase in ACE2 and AT(1-7) in order to maintain the physiologic status quo
[21, 33]. However, in certain disease states, an imbalance between the two arms arises, typically in the form of unopposed ACE/AT2 activity [21]. In fact, we propose, as have others, a bipartite model for the pathogenesis of COVID-19: following an initial phase of illness resulting from direct viral toxicity to target cells, the disease enters an inflammatory phase in which SARS-CoV-2 induces functional ACE2 deficiency. This effective loss of ACE2, in turn, leads to an 
imbalanced RAS with a skewed ratio of AT2 to AT(1-7) [4, 13-15]. It has been argued that this imbalance is a driver of COVID-19 pathology [13-15]. Moving forward, we will examine the evidence in support of this theory first by exploring how ACE2 deficiency itself manifests.

\section{Angiotensin imbalance causes widespread deleterious effects}

Regulation of angiotensin balance by the systemic and local RAS has been confirmed to play a role in optimal functioning of most organ systems [6]. Numerous studies antedating COVID-19 have explored the physiologic consequences of angiotensin imbalance. We will review these data in order to highlight the diverse, multi-system failure that broad ACE2 deficiency incites (Table 1).

Lungs Cytokine signaling increases local ACE production, which in turn promotes the pathologic processes underpinning many features of ARDS: enhanced vasoconstriction and vascular permeability, further cytokine production, apoptosis of alveolar epithelial cells, and fibroproliferation [36, 37]. Indeed, ACE polymorphisms that augment its enzymatic activity correlate with increased mortality in ARDS [22,38]. By contrast, ACE2 deficiency in the setting of superimposed illness can exacerbate acute lung injury or ARDS in animal models secondary to a relative increase in AT2 activation of $\mathrm{AT}_{1} \mathrm{R}$ [10, 36, 39-41], while administration of recombinant ACE2 improves lung pathology [10, 40]. Bronchoalveolar lavage (BAL) fluid from rats with lipopolysaccharide (LPS)induced ARDS likewise contains upregulated ACE at the expense of ACE2, while recombinant AT(1-7) and the $\mathrm{AT}_{1} \mathrm{R}$ antagonist losartan decrease lung inflammation [41].

Cardiovascular system AT2 promotes left ventricular hypertrophy and myocardial dysfunction, while pharmacologic blockade of this pathway has become a cornerstone of the management of both ischemic heart disease and congestive heart failure [23, 42]. Additionally, AT2 is thought to upregulate ADAM17, inducing a shift from membranebound to soluble ACE2, plausibly explaining the strong correlation between circulating SACE2 and cardiovascular morbidity and mortality $[4,43,44]$. To wit, high sACE2 levels in patients with cardiovascular disease (CVD) likely reflect an increased baseline AT2 tone rather than an active pathologic role for sACE2 per se. Downstream off AT2, aldosterone also causes deleterious effects on the cardiovascular system as evidenced by the all-cause mortality benefit conferred by mineralocorticoid receptor antagonists in patients with heart failure with reduced ejection fraction $[45,46]$. The ACE2 pathway likely serves in a counter-regulatory capacity [4, 22]. Data on ACE2 deficiency in compensated states are mixed [47, 48]. However, superimposed insults such as volume overload or AT2 infusion can trigger more overt cardiac dysfunction [47-49]. The effect of ACE2 on heart function may proceed in part through conversion of AT(1-7) to almandine, as loss of the almandine receptor (MrgD) in an animal model results in severe cardiomyopathy [50].

Excretory (renal) system Perhaps the best-known function of AT2 is its regulation of intravascular volume via its effects on renal water and sodium handling [51, 52]. However, a broader spectrum of ACE activity is implicated in chronic kidney disease, including increased oxidative stress, fibrosis, and inflammation [51]. On the other hand, the ACE2 arm largely opposes these effects, resulting in vasodilation, natriuresis and diuresis, and reduced oxidative stress and inflammation [51, 52]. An altered balance of ACE/ACE2 may be an important driver of renal pathology [51-53]. For example, murine knockout of the genes encoding ACE2 or the Mas receptor promotes proteinuria and renal inflammation that is attenuated by treatment with recombinant human ACE2 (rhACE2) [54-56]. The loss of ACE2 potentiates activation of $\mathrm{AT}_{1} \mathrm{R}$ by $\mathrm{AT} 2$, in turn upregulating the oxidative stress response; increased production of cytokines leads to inflammation and breakdown or malfunction of the glomerular filtration barrier [56].

Endocrine system AT2 infusion has been shown to reduce blood flow to pancreatic islet cells, thereby hindering firstphase glucose-stimulated insulin secretion [57, 58]. At higher doses, AT2 may reduce both basal and pulsatile insulin secretion in humans [59-61]. The negative effects of the ACE pathway on insulin production likely result from $\beta$-cell damage from increased oxidative stress and fibrosis as well as specific impairments in insulin synthesis and secretion [59, 61]. Congruently, Ace 2 and MasR knockout mice are glucose intolerant, while treatment of diabetic $o b / o b$ mice with rhACE2 improves hyperglycemia along with indices of $\beta$-cell number and function [62-64]. Additionally, treatment with angiotensin(1-7) enhances insulin secretion in diabetic rats through improvements in $\beta$-cell microperfusion [65].

Neurological system Activation of the ACE arm increases risk of stroke, perhaps secondary to increased vasoconstriction, inflammation, fibrosis, and oxidative stress [66]. Knockout of $\mathrm{AT}_{1} \mathrm{R}$ or administration of an AT2 "vaccine" reduces stroke risk in mice while increased angiotensin-2 levels in mice, via genetic manipulation of the renin and angiotensinogen genes, increases stroke risk [66-69]. The ACE2/AT(1-7) arm is less well characterized but has been identified as a neuroprotective pathway $[66,70]$. In rats, both ACE2 and angiotensin(1-7) are increased within $48 \mathrm{~h}$ of an ischemic stroke, and intracerebroventricular infusion of AT(1-7) or administration of an ACE2 activator can reduce infarct size [71, 72]. 


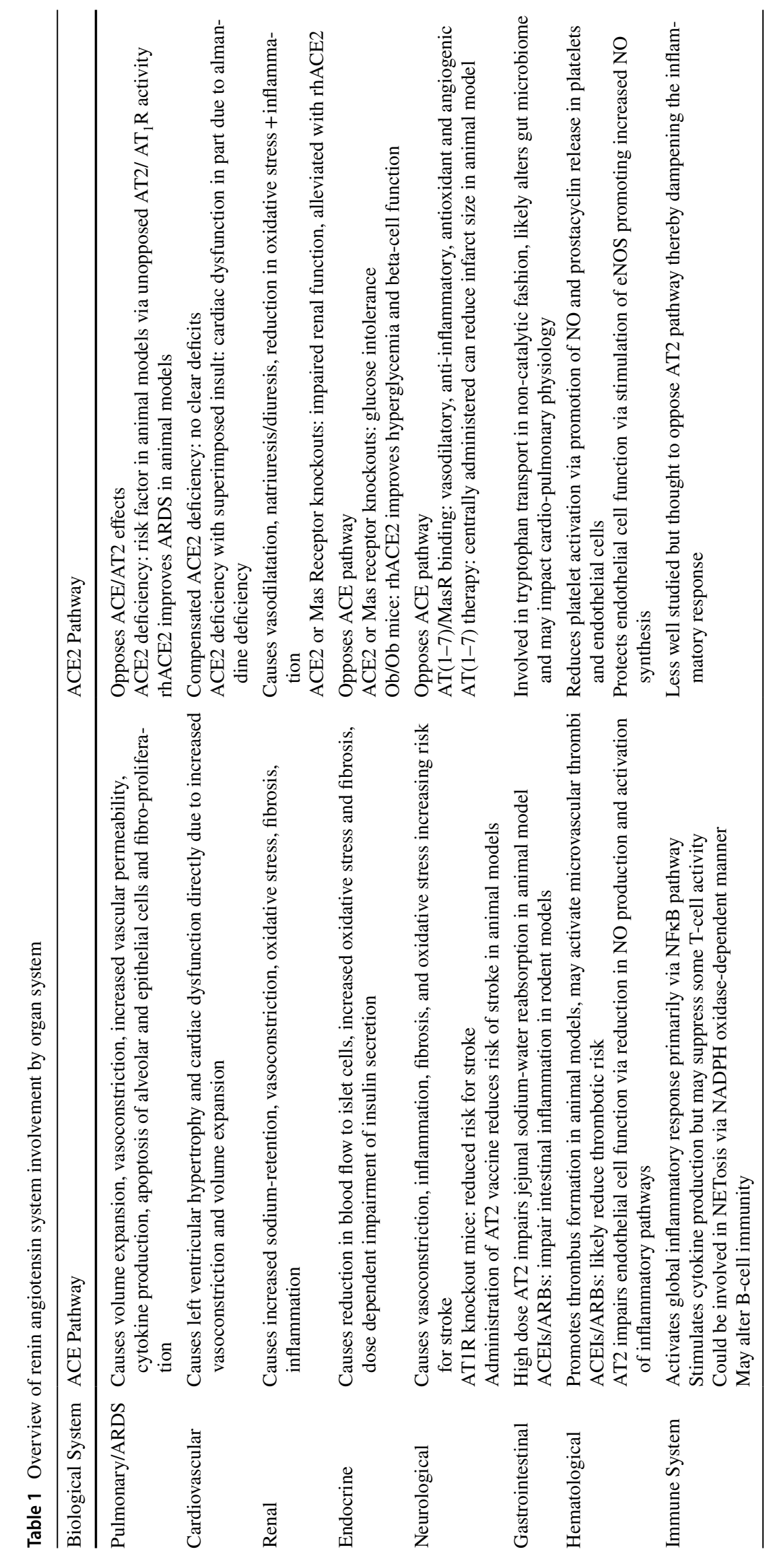


Gastrointestinal system The small intestine hosts the body's highest tissue concentration of both ACE and ACE2 [73]. High doses of exogenous AT2 administered enterally to rats impair jejunal sodium-water reabsorption - potentially explaining the increased risk of diarrhea in COVID-19 - while ACE inhibitors and angiotensin receptor blockers (ARBs) reduce intestinal inflammation in rodent models $[73,74]$. The effects of ACE2 in the gut are less well recognized but it appears to act in a non-catalytic manner to regulate tryptophan transport and the expression of antimicrobial peptides $[4,7,73]$. It has been more broadly hypothesized that ACE2's impact on cardiovascular and pulmonary physiology may also proceed in part through alteration of the gut microbiome [4, 7].

Hematologic The RAS modulates cardiovascular risk beyond the myocardium through direct effects on the vasculature, principally with regard to endothelial cell function and regulation of thrombotic pathways. A detailed accounting of the molecular pathways involved in the effects of the RAS on endothelial cell function is beyond the scope of this review. Nonetheless, activation of the ACE pathway has been shown to promote endothelial cell dysfunction [75-79]. The hallmark of endothelial cell dysfunction is failure to promote vasodilation by vascular smooth muscle cells, for example due to insufficient generation of nitric oxide (NO) by endothelial NO synthase (eNOS) [80]. AT2 and AT(1-7) have been shown to participate in the regulation of this process, as endothelial cells express both AT2 and Mas receptors [78, 81]. Local AT2 may act in a paracrine or endocrine fashion to impair production of NO by endothelial cells [7679]. In an animal model, increasing doses of AT2 stimulated interleukin 6 (IL-6) production and promoted vascular macrophage accumulation, both of which correlated with increasing degrees of endothelial cell dysfunction [75]. By contrast, the ACE2 pathway is felt to protect endothelial cell function [4, 81-83]. AT(1-7) activation of Mas receptors has been shown to stimulate eNOS [83]; the resulting increase in NO synthesis promotes vasodilation as well as anti-fibrotic and anti-inflammatory effects, thereby helping to preserve endothelial cell function. The second major role of the RAS in vascular biology is regulation of thrombotic pathways by AT2 and AT(1-7) [13, 84]. ARBs and ACE inhibitors may reduce thrombosis in an AT(1-7)-dependent manner via enhanced fibrinolysis and reduced platelet activation [84, 85]. AT2 infusion in hypertensive rats promotes thrombus formation, particularly within the microvasculature, in an $\mathrm{AT}_{1} \mathrm{R}$-independent manner [86]. The anti-thrombotic effect of AT(1-7) likely proceeds via activation of MasR on platelets that increases NO release as well as endothelial cell release of $\mathrm{NO}$ and prostacyclin (PC) [84]. Increased local $\mathrm{NO}$ and $\mathrm{PC}$ release reduces platelet activation and promotes vasodilation [84].
Immune system The renin-angiotensin system is intricately involved in both innate and adaptive immunity [4-6, 87-91]. This interaction is highly complex and incompletely understood. Nevertheless, it is important to note some salient points to better contextualize the importance of a balanced RAS for normal immune function. In general, upregulation of the systemic ACE pathway - via activation of NFKB, a key regulator of inflammatory cytokine gene expression leads to a pro-inflammatory state, while ACE2 dampens this inflammatory response [4-6, 89, 90, 92]. In reality, the interaction between the RAS and immune function is far more complex. For instance, more recent data suggest that activation of $\mathrm{AT}_{1} \mathrm{R}$ in lymphocytes tempers the inflammatory response, perhaps in an effort to brake the global inflammation triggered by AT2 [88]. As such, it is plausible that a functional ACE2 deficiency could simultaneously upregulate a systemic inflammatory response while inhibiting certain aspects of T-cell function.

\section{Evidence for ACE2 downregulation model}

\subsection{Clinical similarities between COVID-19 and ACE2 deficiency}

COVID-19 results in broad organ system dysfunction [93, 94]. In its severe form, it leads to life-threatening ARDS and extra-pulmonary manifestations are common [93, 94]. Studies have confirmed an increased risk for cardiovascular dysfunction, acute kidney injury, stroke, exacerbation of pre-existing diabetes or development of new-onset hyperglycemia, gastrointestinal pathology, and thrombosis [93, 94]. Additionally, in an animal model, SARS-CoV-2 has been shown to cause endothelial cell dysfunction via reduction in pulmonary artery endothelial NO synthase activity [95] suggesting that endothelial cell dysfunction plays an important role in COVID-19 pathology [96, 97]. These derangements phenotypically recapitulate functional ACE2 deficiency, solidifying the mechanistic plausibility of this model.

The parallels between the dysregulated immune function that characterizes COVID-19 and ACE2 deficiency are particularly compelling. Dysregulated immunity in COVID-19 may take various forms: cytokine storm, leukopenia, propagation of neutrophil extracellular traps ("NETosis"), and aberrant B-cell function [93, 98-101]. Intriguingly, a dysregulated RAS can produce a similar immunologic fingerprint. For example, unopposed AT2, likely via its functional interaction with NFkB and subsequent upregulation of IL-6, could play an active role in "cytokine storm" [102, 103]. Extrapolating from our discussion above, AT2 may exert direct inhibitory effects on T-cell function - perhaps an explanation for the leukopenia seen in COVID-19 patients [88]. AT2's ubiquitous activation of $\mathrm{AT}_{1} \mathrm{R}$ may also be linked to the development 
of NETosis in an NADPH oxidase-dependent manner [104, 105]. Lastly, the lymph nodes of a subset of COVID-19 patients exhibit loss of germinal centers, thereby impairing durable immunity [100]. Interestingly, expression of B-cell lymphoma 6 protein (BCL6), a well-known regulator of germinal center dynamics, can be suppressed by AT2 [106-108]. Overall, experimental data support a negative impact of functional ACE2 deficiency on both innate and adaptive immunity.

\subsection{Mechanisms of SARS-CoV-1 and -2 infection}

The close resemblance of the multisystem pathology of COVID-19 to the physiologic consequences of angiotensin imbalance described above suggests but does not prove that SARS-CoV-2 infection causes functional ACE2 deficiency. However, the closely related SARS-CoV-1, which also caused both pulmonary and diffuse extra-pulmonary complications [109, 110], has been shown to downregulate ACE2 [10-12]. SARS-CoV-2 does appear more infectious perhaps secondary to its use of three additional viral cofactors: neuropilin-1 (NRP-1), HDL scavenger receptor B1 (SR-B1), and CD147 [111-113]. Interestingly, AT2 has been linked to upregulation of these co-receptors [114-118]. If these findings are confirmed in COVID-19, it would suggest a pathologic feed-forward cycle in which the SARSCoV-2-mediated decrease in ACE2 leads to a downstream proliferation of viral co-receptors. Despite this important difference between SARS-CoV-1 and SARS-CoV-2, the similar clinical characteristics of the two viral infections is compelling. It may speak to ACE2's ubiquity and simply reflect direct viral toxicity to a variety of target cell types but alternatively, the data could support the loss of ACE2 function per se as a key driver of disease.

To understand how SARS-CoV-2 could induce a functional ACE2 deficiency, one must look to its site of cell entry at the plasma membrane. SARS-CoV-2 binding to ACE2 activates two important enzymes: ADAM17 and transmembrane protease serine 2 (TMPSSR-2), both of which cleave membrane-bound ACE2 (mACE2) but do so at distinct sites [119]. Cleavage of ACE2 by ADAM17 results either in internalization of ACE2 by endocytosis or release of soluble ACE2 (sACE2), which retains some catalytic activity, into the extracellular fluid [119]. By contrast, TMPSSR-2 cleavage of ACE2 leads only to ACE2 internalization and, presumably, loss of function [119]. The reduction in mACE2 activity likely sets the stage for an imbalance between the key RAS effector peptides, AT2 and AT(1-7). Relatively unopposed AT2 activity can propagate the angiotensin imbalance by promoting further downregulation of mACE2 through its activation of ADAM 17 [4, 120]. Although plasma ACE2 activity rises during COVID-19 and may remain increased for weeks [121], it is not clear that this increase represents the full catalytic potential of ACE2 due to the possible presence of circulating endogenous inhibitors [122]. Additionally, the loss of mACE2's obligatory localization once solubilized prevents the enzyme from acting efficiently in the original tissue microenvironment where it may be needed most. Interestingly, SARS-CoV-2 may also co-opt rising sACE2 levels in service of cell entry by forming ternary complexes with sACE2 and vasopressin that can be internalized upon binding to $\mathrm{AT}_{1} \mathrm{R}$ and vasopressin receptors [123]. Formation of such viral-protein complexes may further attenuate sACE2 activity, thereby compounding functional ACE2 deficiency.

In summary, there is good evidence to support SARSCoV-1 downregulation of ACE2 [10-12]. Until recently, direct evidence for ACE2 downregulation by SARS-CoV-2 was lacking, but a new study reports that its spike protein is able to induce downregulation of ACE2 in hamster lung tissue and in human pulmonary artery endothelial cells [95]. To the best of our knowledge, this is the only study directly demonstrating ACE2 downregulation by SARS-CoV-2. Nonetheless, given the similarities between SARS-CoV-1 and SARS-CoV-2, coupled with the strong mechanistic possibility of ADAM17- and TMPSSR-2-mediated ACE2 shedding, it is reasonable to suspect that ACE2 downregulation occurs in COVID-19. Furthermore, given that COVID-19 closely phenocopies SARS - a disease state in which ACE2 downregulation is established - ACE2 downregulation is likely an important aspect of COVID-19 pathology. Indeed, multiple other lines of evidence that we will review support the ACE2 downregulation model.

\subsection{Epidemiologic data}

Additional support for the ACE2 deficiency model may lie in a more detailed examination of high-risk patient populations. Numerous groups have been identified as at high risk for poor COVID-19 outcomes: male gender, older age, obesity, and pre-existing co-morbidities with heart disease, hypertension, diabetes, and possibly vitamin $\mathrm{D}$ deficiency [93, 124-127]. These high-risk groups for COVID-19 share at least one common factor: elevated baseline ACE pathway tone, which may arise from the increased prevalence of chronic inflammation in many of these groups [87, 128-132]. Unsurprisingly, modulation of this pathway with $\mathrm{ACE}$ inhibitors or ARBs is common practice in many of these patient cohorts. Less well known but equally compelling is the evidence for direct interaction of both testosterone and vitamin D with the ACE pathway [133-140]. Studies predating COVID-19 have shown that testosterone can potentiate AT2 activity, in part via modulation of the relative levels of each angiotensin receptor [133-136]. Additionally, vitamin $\mathrm{D}$ deficiency may adversely impact on the RAS. Calcitriol suppresses renin gene expression and potentiates the angiotensin(1-7) arm, and was shown to improve 
LPS-induced ARDS in rats through favorable changes in both RAS arms [137-140].

Our understanding of baseline ACE2 activity in these high-risk populations is far less extensive due to an overall paucity of data, inconsistent reporting of endpoints across studies (e.g., ACE2 levels vs. activity, soluble vs. membranebound ACE2, angiotensin-2 vs. angiotensin (1-7) levels), and the innate complexity of ACE2 regulation. ACE2 activity can vary by organ system within a single disease state, as well as within an individual organ system based on clinical status (e.g., compensated or decompensated heart failure) [141, 142]. Definitively characterizing baseline ACE2 status, therefore, is challenging; any discussion must be tissue specific and clearly delineate the endpoint(s) under evaluation. For example, in nasal epithelium, a critical site of SARSCoV-2 entry, ACE2 gene expression increases with age [143]. Similarly, a recent study found ACE2 gene expression in airway epithelial cells higher in older male patients, even as its expression pattern varied in other organs and in women [144, 145]. Lastly, sACE2 levels are elevated in numerous high-risk groups [43, 44, 146].

By contrast, epidemiologically low-risk groups - primarily women and younger patients - benefit from lower baseline ACE activity. Children generally lack chronic comorbidities that could drive inflammation-based activation of the RAS [87]. Direct assessment of ACE2 levels are complicated for reasons aforementioned but ACE2 expression may be lower in multiple organ systems in younger patients [143, 145]. The lower risk of women is likely attributable to a high ratio of estrogen to testosterone. The effects of estrogen on the RAS are complex but on the whole, in contrast to testosterone, it tilts the balance toward angiontensin(1-7), both via attenuation of the ACE pathway and upregulation of the ACE2 pathway $[135,136,147-149]$. The ACE2 gene promoter contains numerous estrogen and androgen receptor binding motifs - the former outnumbering the latter - suggesting direct regulation of the ACE2 pathway by sex steroids [145]. If ACE2 levels are upregulated in women, it is important to note this would reflect a non-compensatory, or "primary", increase, in stark contrast to high-risk patients. As such, according to this model, higher ACE2 levels may increase risk for initial infection in women but, as with children, a favorable initial ratio of AT2 to AT(1-7) would position them to fare better once infected.

In summary, the critical difference between high- and low-risk groups relates to baseline ACE tone and the nature of their baseline ACE2 status. High-risk groups start out with a relatively high basal ACE tone while low-risk groups do not. Characterizing differences in ACE2 status is more difficult but the dynamic relationship between the two arms of the RAS is far more important than a single snapshot of ACE2 levels. Increased levels of ACE2 in high-risk patients, if present, likely reflect a compensatory attempt to counter a tonically activated ACE pathway. These patients have little or no ACE2 "buffer", and any loss of ACE2 translates immediately into excess AT2, setting the stage for a more severe disease course. By contrast, for patients at lower risk, relatively elevated levels of ACE2 are "primary" rather than compensatory as their basal ACE tone is relatively low. As such, these low-risk patients benefit from a built-in AT(1-7) "buffer" that helps to forestall the development of relative AT2 excess.

\subsection{Clinical trial data}

The compendium of COVID-19 therapeutic trials performed within the past year also hint at involvement of the RAS in COVID-19 pathology. Each of the following agents require further study to confirm their true impact on COVID-19, and each may have RAS-independent effects that could help explain the findings. It is intriguing, however, that they all interact with the RAS; collectively these studies add to the body of evidence favoring a skewed RAS as a cardinal feature of COVID-19 pathophysiology.

ACEI/ARB studies The most obvious candidates for demonstration of perturbations of the RAS in the pathophysiology of COVID-19 are ACE inhibitors (ACEI) and angiotensin receptor blockers (ARB). Unsurprisingly, multiple such studies have been conducted [150-160] (Table 2). Unfortunately, the data are mixed and significantly confounded for numerous reasons: most are observational studies, medications have typically been stopped once patients are hospitalized, and most authors combine ACEI and ARB use without considering differences between these two medication classes. Nonetheless, the overwhelming consensus that has emerged is that ACEIs and ARBs are not contraindicated despite the potential for upregulation of ACE2. A large meta-analysis assessed 86 studies involving 459,755 patients and found no increased risk for infection or severe infection among hypertensive patients on ACEIs or ARBs [156]. In fact, there appears to be a possible survival benefit with their use (OR 0.75, 0.61-0.92). Additional, smaller studies have also hinted at improved outcomes, especially among subgroup analysis of hypertensive patients, but this finding has not been universal [151, 153-155, 159].

The relatively modest results with ACEIs and ARBs do raise some fundamental questions regarding the ACE2 downregulation hypothesis. Confounding aside, a clear reduction in mortality might be expected if the hypothesis is correct, but several additional factors must be considered. For example, ACE inhibitors alone do not completely curtail AT2 production: studies predating COVID-19 have confirmed ACE-independent production of AT2, most notably by chymase derived from mast cells $[6,22,26,161]$. 


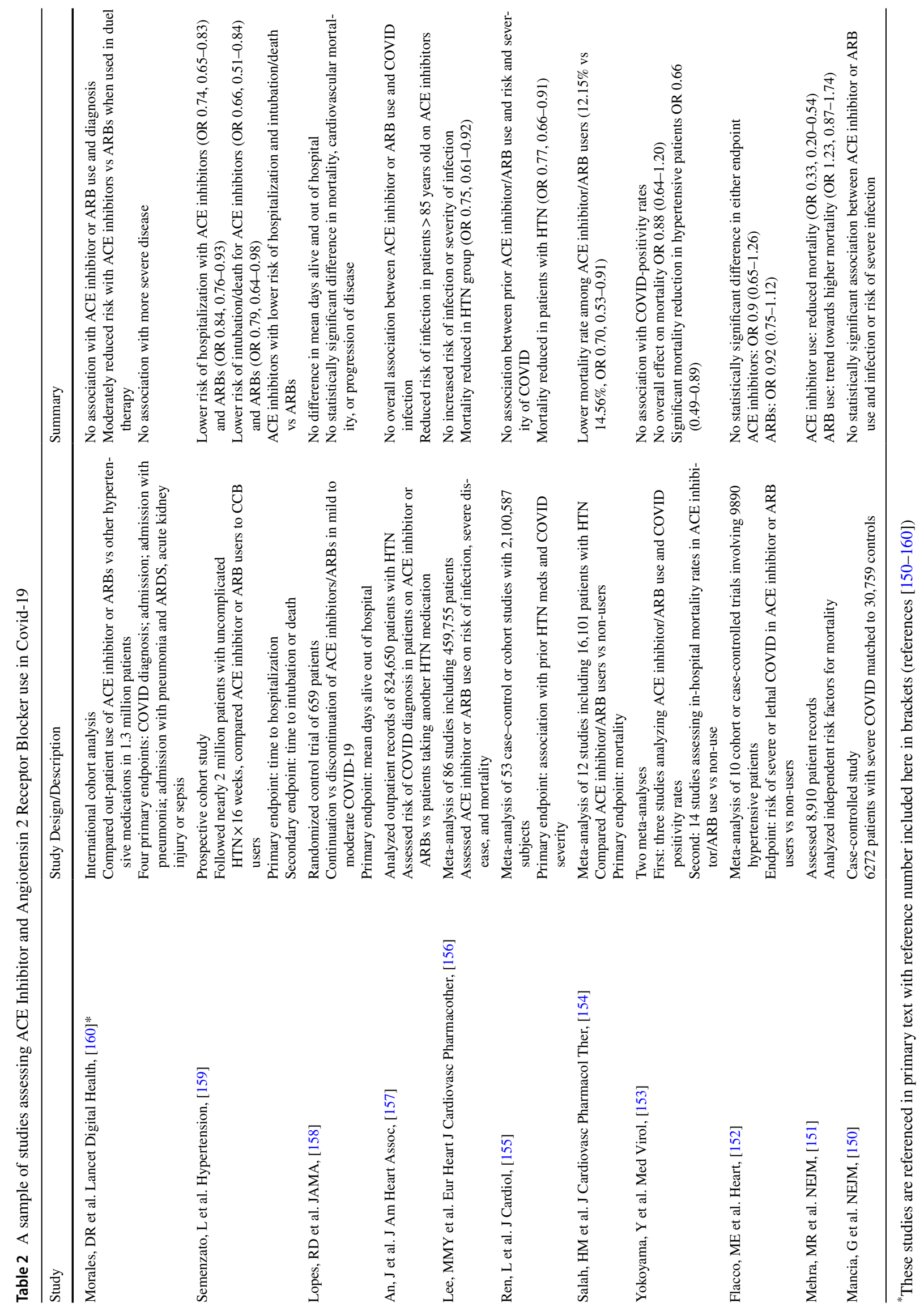


Perhaps not coincidentally, mast cell activity is thought to be increased in COVID-19, providing a viable alternative source for ongoing AT2 production in the face of ACE inhibition [162]. Furthermore, ACE inhibitors impair the ACEmediated breakdown of bradykinin, compounding the effect of ACE2 depletion. Increased levels of bradykinin may further activate chymase pathways to establish a vicious feedforward cycle [35]. Given these alternative mechanisms, ACE inhibition may not be sufficient to reduce AT2 activity.

Similarly, the modest effect of ARB treatment may be due to several additional factors. For one, their use is known to cause a compensatory rise in AT2 which has been shown to induce microvascular thrombosis in an $\mathrm{AT}_{1} \mathrm{R}$-independent fashion [86]. Although $\mathrm{AT}_{1} \mathrm{R}$ is blocked, AT2 can also be converted to angiotensin- 3 and angiotensin- 4 [163]. These peptide fragments, though not well studied, may cause harm not suppressible by $\mathrm{AT}_{1} \mathrm{R}$ blockade. For instance, it is thought that angiotensin- 4 raises thrombotic risk by increasing plasminogen activator inhibitor-1 $[163,164]$. Furthermore, the downstream effects of $\mathrm{AT}_{1} \mathrm{R}$ activation entail certain subtleties that would be lost with wholesale blockade by ARBs. These include, first, the possibility of differential activation by "biased agonists" that bind $\mathrm{AT}_{1} \mathrm{R}$ and oppose the actions of classical AT2/AT ${ }_{1} \mathrm{R}$ signaling [23]. Second, activation of $\mathrm{AT}_{1} \mathrm{R}$ in lymphocytes appears to attenuate their immune response, contrary to the generally pro-inflammatory theme of $\mathrm{AT}_{1} \mathrm{R}$ activation, as a check against runaway inflammation [88]. At the same time, buildup of AT2 in the setting of $\mathrm{AT}_{1} \mathrm{R}$ blockade would be expected to translate into an increase in $\mathrm{AT}_{2} \mathrm{R}$ signaling that would oppose some of the effects of AT2/ $\mathrm{AT}_{1} \mathrm{R}$ activation [23, 24]. Overall, the complex interplay between the various peptides and receptors of the conventional ACE pathway poses challenges in predicting a straightforward response to $\mathrm{AT}_{1} \mathrm{R}$ blockade in the context of ACE2 deficiency.

Glucocorticoids One of the most important milestones in the development of effective COVID-19 treatment was the discovery that dexamethasone reduces mortality in patients receiving supplemental oxygen or ventilator assistance [165]. Dexamethasone's main impact on COVID-19 may be through its known anti-inflammatory effect. However, glucocorticoids also have a strong, albeit complicated, relationship with the RAS (Table 3). Glucocorticoids appear to upregulate the ACE pathway in animal models by inducing synthesis of $\mathrm{ACE}$, angiotensinogen, and $\mathrm{AT}_{1} \mathrm{R}$ in smooth muscle cells, and by potentiating AT2-mediated vasoconstriction [166-168]. On the other hand, steroids may impair ACE-independent AT2 production by diminishing mast cell numbers and activity [169]. Glucocorticoids are also thought to upregulate neprilysin, a key ACE2-independent mediator of AT1 to AT(1-7) conversion, and may downregulate bradykinin receptors; reduction in bradykinin-stimulated chymase activity is thereby expected to further curb AT2 production [170-173]. Dexamethasone also favorably affects mineralocorticoid receptor activity. By suppression of adrenocorticotropic hormone (ACTH), dexamethasone can profoundly reduce the high levels of endogenous cortisol expected in critical illness that can cross-stimulate the mineralocorticoid receptor. Finally, glucocorticoids have been shown to inhibit NFKB, which mediates many of the pro-inflammatory actions of AT2 $[89,102,174]$. Thus, dexamethasone's beneficial effect in COVID-19 could speak to its impact on the RAS through multifactorial rebalancing ACE/AT2 and ACE2/AT(1-7).

Aspirin A retrospective observational cohort study of 98 patients who received aspirin within $24 \mathrm{~h}$ of admission or 7 days prior to admission found a reduced risk of mechanical ventilation, ICU admission, and mortality relative to 314 controls [175]. This finding has not yet been validated by a prospective clinical trial. It is presumed that the principal mechanism is via aspirin's well-established anti-platelet or anti-inflammatory effects. However, aspirin may also counteract some deleterious effects of AT2, potentially through inhibition of NFKB activation and preservation of endothelial cell function through promotion of nitric oxide release [176-179]. Additionally there is evidence that aspirin can down-regulate $\mathrm{AT}_{1} \mathrm{R}[180,181]$.

Statins A recent large retrospective study of COVID-19 patients analyzed 648 statin users vs controls and found a significant reduction in mortality [182]. Considerable data support a direct link between statins and downregulation of the ACE pathway suggesting that statins decrease AT2 receptor expression, inhibit AT2-induced downstream signaling, reduce AT2-mediated oxidative stress, and potentially impair AT2 and aldosterone production [183]. Furthermore statins might potentiate the ACE2/AT(1-7) pathway [184].

Metformin The authors of a retrospective analysis of 25,326 subjects tested for COVID-19 at one tertiary care center found a significant reduction in mortality in patients treated for diabetes with metformin [185]. If this benefit is proven in larger, prospective, randomized studies, the mechanism will likely be multifactorial. However, in numerous animal models, metformin has been shown to down-regulate $\mathrm{AT}_{1} \mathrm{R}$ and antagonize AT2 pathways [186-188].

Recombinant ACE2 Treatment of COVID-19 in a patient requiring mechanical ventilation with recombinant soluble human ACE2 quickly raised AT(1-7) levels at the expense of AT2 [189]. Viral load fell by two orders of magnitude within two days of starting treatment, while markers of endothelial function and levels of pro-inflammatory 
Table 3 Medications with positive endpoints in COVID-19 and their potential association with RAS

\begin{tabular}{|c|c|c|}
\hline Drug Therapy & Study Design + Findings & Proposed Association to RAS \\
\hline Dexamethasone & $\begin{array}{l}\text { Design: randomized open label trial of } 6,425 \text { patients } \\
\text { Protocol: Randomized to dexamethasone } 6 \mathrm{mg} \times 10 \text { days vs } \\
\text { standard of care } \\
\text { Findings: } 28 \text {-day mortality improved in patients receiving } \\
\text { oxygen and/or mechanical ventilation }\end{array}$ & $\begin{array}{l}\text { ACE Pathway: } \\
\text {-Induces synthesis of ACE, AT1 and } \mathrm{AT}_{1} \mathrm{R} \\
\text {-Potentiates AT2 vasoconstriction } \\
\text {-Suppresses AT2 induced inflammation (via effects on } \\
\text { NFKB) } \\
\text { ACE2 Pathway } \\
\text {-Suppress non-ACE mediated AT2 production } \\
\text {-Increase AT }(1-7) \text { levels via NEP mediated activation }\end{array}$ \\
\hline Aspirin & $\begin{array}{l}\text { Design: retrospective, observational cohort study involving } \\
412 \text { patients } \\
\text { Protocol: } 98 \text { patients received ASA within 24-h of admis- } \\
\text { sion or 7-days prior } \\
\text { Findings: reduction in risk for mechanical ventilation, ICU- } \\
\text { admission, and in-hospital mortality }\end{array}$ & $\begin{array}{l}\text { ACE Pathway: } \\
\text {-Protects against AT2-induced end organ damage via } \\
\text { inhibition of } \mathrm{NF}_{\mathrm{K}} \mathrm{B} \text { and promotion of NO release in } \\
\text { endothelial cells } \\
\text {-Downregulates } \mathrm{AT}_{1} \mathrm{R}\end{array}$ \\
\hline Statin & $\begin{array}{l}\text { Design: retrospective study of } 648 \text { matched COVID-19 } \\
\text { patients vs controls } \\
\text { Findings: significant reduction in mortality in COVID-19 } \\
\text { patients taking statins }\end{array}$ & $\begin{array}{l}\text { ACE Pathway: } \\
\text {-Decreases AT } \mathrm{R}_{1} \text { expression } \\
\text {-Inhibits AT2 down-stream signaling } \\
\text {-Impairs AT2 and aldosterone production } \\
\text { ACE2 Pathway } \\
\text {-Upregulates ACE2 and AT(1-7) pathway }\end{array}$ \\
\hline Metformin & $\begin{array}{l}\text { Design: retrospective study } 25,326 \text { patients at one tertiary } \\
\text { center } \\
\text { Findings: significant reduction in mortality in DM patients }\end{array}$ & $\begin{array}{l}\text { ACE Pathway: } \\
\text {-Inhibits } \mathrm{AT}_{1} \mathrm{R} \text { expression } \\
\text {-Antagonizes AT2 pathways }\end{array}$ \\
\hline Recombinant ACE2 & $\begin{array}{l}\text { Design: case study } \\
\text { Findings: } 45 \text {-year-old woman with DM2 admitted with } \\
\text { 7-days cough, weakness, myalgia, fever, dyspnea and } \\
\text { 4-days GI symptoms. Course worsened requiring intuba- } \\
\text { tion. Hospital day } 2 \text { started rhACE2 bid × } 7 \text { days. Defer- } \\
\text { vesced after first dose. AT(-1-7) levels rose, AT2 levels } \\
\text { fell. Markers of endothelial cell function and inflammatory } \\
\text { markers improved as did overall clinical picture }\end{array}$ & $\begin{array}{l}\text { ACE Pathway: } \\
\text {-Retains ACE2 catalytic function } \\
\text {-Decreases AT2 levels } \\
\text { ACE2 Pathway: } \\
\text {-Increases AT(1-7) levels }\end{array}$ \\
\hline $\mathrm{C} 21$ & $\begin{array}{l}\text { Design: double-blind RCT of } 106 \text { patients } \\
\text { Protocol: COVID- } 19 \text { patients with high CRP but not on } \\
\text { mechanical ventilation, randomized to C } 21 \times 7 \text { days or } \\
\text { standard of care } \\
\text { Finding: at day } 14,90 \% \text { reduction in need for supplemental } \\
\text { O2 } \\
\text { NOT YET PEER REVIEWED }\end{array}$ & $\begin{array}{l}\text { ACE Pathway } \\
\text {-Stimulates AT2R receptors } \\
\text {-Opposes some activity of AT- } 2 / \mathrm{AT}_{1} \mathrm{R} \text { signaling } \\
\text { ACE2 Pathway: } \\
\text {-May act as functional equivalent of a partial ACE2 activa- } \\
\text { tor }\end{array}$ \\
\hline
\end{tabular}

cytokines - as well as the overall clinical picture - markedly improved. Recombinant ACE2 likely restores healthier angiotensin balance while simultaneously serving as a decoy receptor for SARS-CoV-2. Although sACE2 may enhance SARS-CoV-2 cell entry via $\mathrm{AT}_{1} \mathrm{R}$ in cultured cells, this rhACE2 trial suggests that it may not be as significant a pathway in humans [123]. It is difficult to parse out the specific impact of this treatment within the overall intensive care milieu and the variable natural history of the illness but the striking temporal effect of the treatment lends credence to the ACE2 deficiency model

$\mathrm{AT}_{2} \mathrm{R}$ agonist $\mathrm{A}$ recent randomized clinical trial employing a "first in class" agonist of $\mathrm{AT}_{2} \mathrm{R}$ has demonstrated reduced oxygen requirements and trends toward reduced intubation and mortality, although the data are not yet peer reviewed [Tornling $\mathrm{G}$ et al., 2021]. Our understanding of the $\mathrm{AT}_{2} \mathrm{R}$ remains very incomplete though evidence suggests that activation of this receptor opposes some functions of AT2/AT1R signaling thereby paralleling increased ACE2 activity [23, 24].

\section{Evidence against the ACE2 deficiency model?}

While we have shown the growing evidence in support of the theory that ACE2 down-regulation by SARS-CoV-2 is a critical driver of COVID-19 pathology, there are lingering, important concerns about the accuracy of the model. 


\section{Is ACE2 downregulated by SARS-CoV-2?}

Most of the support for downregulation in vivo are limited to studies of the isolated SARS-CoV-2 spike protein [95] or of SARS-CoV-1 infection in mice [10-12]. However, human - but not mouse - airway epithelial cells appear capable of upregulating ACE2 in response to the burst of interferon signaling expected to accompany SARS-CoV-2 infection [19]. Beyond interferon, in vitro work has even suggested direct enhancement of ACE2 catalytic activity by SARS$\mathrm{CoV}-2$ or its isolated spike protein, particularly with regard to the active metabolite of bradykinin [190, 191]. It is difficult to extrapolate these data to the in vivo situation, however, as one study was performed in a cell-free system using only soluble ACE2 [190], and a second study confirmed the spike protein did downregulate ACE2 in vivo [95]. These divergent findings highlight that viral potentiation of ACE2 activity and downregulation of ACE2 need not be mutually exclusive, a distinction necessarily lost in a cell-free system. Crucially, despite a general increase in ACE2 activity, its metabolism of AT2 was minimally affected by the presence of the virus or its spike protein. Finally, the spike protein of SARS-CoV-1 was also found to accelerate ACE2 activity despite its likely ability to trigger downregulation of membrane-bound ACE2 [190].

\section{Clinical Studies}

We have only scanty, mixed data on the status of the RAS in humans with COVID-19. In one study, BAL fluid from patients with COVID-19 contained increased ACE2 mRNA relative to controls while that of ACE was decreased [34]. However, no assessment was made of protein levels or activity of ACE2 versus ACE, nor of AT2 versus AT(1-7) levels. The increase in ACE2 mRNA may therefore have been a compensatory mechanism occurring in the setting of already established ACE and AT2 excess. Moreover, ongoing ACE-independent production of AT2 may play an important role in angiotensin balance within the ARDS microenvironment [22, 26, 161]. A second study of SARS-CoV-2-infected lung tissue found increased ACE2 expression at up to $48 \mathrm{~h}$, while prior studies suggested immediate ACE2 downregulation by SARS-CoV-1 $[12,16]$. As previously mentioned, this study is supported by additional data showing upregulation of ACE2 in lung epithelial cells upon infection $[17,18]$. However, the relatively short observation window in these studies may not be generalizable to later changes in ACE2 levels. Based on the previously mentioned bipartite nature of COVID19 , an early interferon-induced upregulation of ACE2 in response to initial viral infection may later give way to virus-induced ACE2 downregulation as viral multiplication overwhelms the stimulatory effects of interferon. This proposition is particularly salient given the latency period of up to two weeks between initial infection and onset of severe disease [20].

A related challenge to the model arises from difficulties in evaluating RAS peptides in COVID-19. This challenge may be more problematic insofar as AT2 and AT(1-7) are the main downstream effectors of the two RAS arms; thus their relative levels would be expected to better reflect the prevailing RAS tone than would levels of their upstream converting enzymes. Surprisingly, few such studies exist, but the data available do not convincingly or consistently demonstrate AT2/AT(1-7) imbalance [192-196]. In an early study, the authors found elevated AT2 levels in COVID-19 patients that correlated with degree of illness [193]. However, the study only contained 12 subjects, the authors compared values to healthy controls and the findings have since been questioned due to concerns about methodology [193, 195]. Two subsequent studies found no evidence for increased AT2 levels but critically neither measured AT(1-7), thus preventing interpretation of angiotensin balance in this setting [194, 195]. Another, more recent paper cited reductions in renin, AT1, AT2, and AT(1-7) in COVID-19 patients relative to patients with other respiratory illnesses; in this study, the decrease in AT2 exceeded that of AT(1-7) [192]. However, it is important to interpret these data in view of their limitations: $50 \%$ of the COVID-19 patients did not qualify for inclusion and the heart rate of the control group was statistically greater [192]. The latter could indicate a more severe degree of illness in the control group, as alterations in volume status or evolving sepsis are expected to stimulate the ACE pathway. Different interpretations of the data are also possible when taking into account the significant gaps in our knowledge of this complex system. These include, for example, inopportune timing of sample collection within the course of disease as previously mentioned, as well as the possibility that serum levels of the RAS peptides do not serve as a reliable surrogate for tissue or intracellular levels $[6,26]$. With the potential upregulation of mast cell-derived chymase activity, it is conceivable AT2 levels within tissues are high in COVID-19 patients independent of serum levels [162]. As the authors found low AT(1-7) levels, prior systemic or ongoing local RAS imbalance remains plausible [192].

Further highlighting the enigmatic volatility of the RAS, another group has shown just the opposite of these studies: reduced levels of AT(1-7) while AT2 levels were preserved, albeit with the caveat that levels of the two angiotensins were reported in separate publications drawn from a single common batch of patient samples [195, 196]. This group also found decreased levels of AT1, which they construe as evidence of global RAS downregulation [196]. However, we 
can alternatively interpret the low AT1 levels as a reflection of rapid turnover in order to maintain the relatively high AT2 levels they report, particularly as angiotensinogen levels were not measured [196].

These mixed data do not unequivocally support the ACE2 downregulation model but limitations, both methodologic and inherent to the system itself, muddy interpretation of the data. We note in particular the considerable variability in AT2 levels, as some studies report a range of values spanning two orders of magnitude even within a single patient group. This may be due to technical issues with sample handling or non-standardized assay performance but also may simply reflect extreme biological variation within a notoriously mercurial system [192-196].

Overall, unanswered questions pertaining to the ACE2 deficiency model remain. Most importantly, more definitive data in support of actual downregulation are needed. Thus far the most relevant evidence emerges from mouse experiments in the SARS-CoV-1 literature, highlighting the need for human studies to quell any lingering doubt of ACE2 downregulation. If confirmed, additional studies demonstrating that such downregulation does drive the endothelial cell dysfunction and dysregulated immunity seen with COVID19 would cement the ACE2 deficiency angiotensin imbalance hypothesis as a central explanatory model. To date, however, the current data support the possibility of a delayed ACE2 deficiency occurring later in the disease process.

\section{Conclusions}

SARS-CoV-2 is a novel coronavirus that causes COVID19. Early studies confirmed the virus uses ACE2, a key regulatory enzyme in the RAS, as its primary cell receptor. Drawing from studies with SARS-CoV-1, many have speculated that SARS-CoV-2 downregulates ACE2, creating a functional deficiency that may define COVID-19. In this review, we have dissected the merits of this argument. Confirmatory evidence for this theory is clearly limited and the available data would suggest early upregulation of ACE2 by the immune response, even as ACE2 downregulation has also been demonstrated in endothelial cells exposed to the SARS-CoV-2 spike protein. It is therefore entirely conceivable that COVID-19 pathology simply reflects the ubiquity of the ACE2 receptor facilitating widespread viral cytotoxicity. Yet, on many levels the ACE2-downregulation hypothesis fits with the data currently available. The parallels between the clinical picture seen with COVID-19, as with SARS, and the expected consequences of multi-system ACE2 deficiency are striking. Unifying pathologic themes that may link the multiorgan pathology of COVID-19 to ACE2 deficiency include the endothelial cell dysfunction and immune dysregulation that arise in the setting of angiotensin imbalance. We feel that the preponderance of evidence points to RAS dysregulation - even if confined to individual tissues - occurring as a relatively late event in the pathogenesis of COVID-19, which would support its primacy in driving the deadly second, inflammatory phase of the disease.

\section{Summary key points}

1. This paper explores the hypothesis that ACE2 downregulation plays a central role in COVID-19 pathology

2. Data support a biphasic model of COVID-19 pathophysiology, in which initial interferon-driven upregulation of ACE2 during a phase of direct viral toxicity is later superseded by viral-induced ACE2 downregulation. ACE2 downregulation plays an important role in the second phase of COVID-19 pathology.

3. ACE2 deficiency, possibly confined to the tissue or cellular level, appears to drive the inflammatory phase of COVID-19

a. The inflammatory phase of COVID-19 phenocopies ACE2 deficiency

b. COVID-19 clinically parallels SARS-CoV-1 disease in which ACE2 downregulation is better established

c. High- and low-risk groups for COVID-19 can be risk stratified by baseline RAS balance

d. Multiple clinical studies have shown some benefit in COVID-19 with therapies expected to favorably alter RAS balance

4. Additional evidence particularly in human studies are needed to confirm this hypothesis

Authors contributions Equal.

\section{Declarations}

Conflict of interest No conflict of interest.

\section{References}

1. Hoffmann M, Kleine-Weber H, Schroeder S, Kruger N, Herrler T, Erichsen S, et al. SARS-CoV-2 cell entry depends on ACE2 and TMPRSS 2 and is blocked by a clinically proven protease inhibitor. Cell. 2020;181(2):271-280 e8. https://doi.org/10.1016/j. cell.2020.02.052.

2. Walls AC, Park YJ, Tortorici MA, Wall A, McGuire AT, Veesler D. Structure, Function, and Antigenicity of the SARS-CoV-2 Spike Glycoprotein. Cell. 2020;181(2):281-292 e6. https://doi.org/10.1016/j.cell.2020.02.058. 
3. Li W, Moore MJ, Vasilieva N, Sui J, Wong SK, Berne MA, et al. Angiotensin-converting enzyme 2 is a functional receptor for the SARS coronavirus. Nature. 2003;426(6965):450-4. https://doi. org/10.1038/nature02145.

4. Gheblawi M, Wang K, Viveiros A, Nguyen Q, Zhong JC, Turner AJ, et al. Angiotensin-Converting Enzyme 2: SARS-CoV-2 receptor and regulator of the renin-angiotensin system: celebrating the 20th anniversary of the discovery of ACE2. Circ Res. 2020;126(10):1456-74. https://doi.org/10.1161/CIRCRESAHA. 120.317015 .

5. Tikellis C, Thomas MC. Angiotensin-Converting Enzyme 2 (ACE2) Is a key modulator of the renin angiotensin system in health and disease. Int J Pept. 2012;2012: 256294. https://doi. org/10.1155/2012/256294.

6. Paul M, Poyan Mehr A, Kreutz R. Physiology of local reninangiotensin systems. Physiol Rev. 2006;86(3): 747-803. https:// doi.org/10.1152/physrev.00036.2005.

7. Cole-Jeffrey CT, Liu M, Katovich MJ, Raizada MK, Shenoy V. ACE2 and microbiota: emerging targets for cardiopulmonary disease therapy. J Cardiovasc Pharmacol. 2015;66(6):540-50. https://doi.org/10.1097/FJC.0000000000000307.

8. Donoghue M, Hsieh F, Baronas E, Godbout K, Gosselin M, Stagliano N, et al. A novel angiotensin-converting enzymerelated carboxypeptidase (ACE2) converts angiotensin I to angiotensin 1-9. Circ Res. 2000;87(5):E1-9. https://doi.org/10. 1161/01.res.87.5.e1.

9. Sodhi CP, Wohlford-Lenane C, Yamaguchi Y, Prindle T, Fulton WB, Wang S, et al. Attenuation of pulmonary ACE2 activity impairs inactivation of des- $\operatorname{Arg}(9)$ bradykinin/BKB1R axis and facilitates LPS-induced neutrophil infiltration. Am J Physiol Lung Cell Mol Physiol. 2018;314(1):L17-31. https://doi.org/ 10.1152/ajplung.00498.2016.

10. Kuba K, Imai Y, Rao S, Gao H, Guo F, Guan B, et al. A crucial role of angiotensin converting enzyme 2 (ACE2) in SARS coronavirus-induced lung injury. Nat Med. 2005;11(8):875-9. https://doi.org/10.1038/nm1267.

11. Oudit GY, Kassiri Z, Jiang C, Liu PP, Poutanen SM, Penninger JM, et al. SARS-coronavirus modulation of myocardial ACE2 expression and inflammation in patients with SARS. Eur J Clin Invest. 2009;39(7):618-25. https://doi.org/10.1111/j.1365-2362. 2009.02153.x.

12. Glowacka I, Bertram S, Herzog P, Pfefferle S, Steffen I, Muench MO, et al. Differential downregulation of ACE2 by the spike proteins of severe acute respiratory syndrome coronavirus and human coronavirus NL63. J Virol. 2010;84(2):1198-205. https:// doi.org/10.1128/JVI.01248-09.

13. Verdecchia P, Cavallini C, Spanevello A, Angeli F. The pivotal link between ACE2 deficiency and SARS-CoV-2 infection. Eur J Intern Med. 2020;76:14-20. https://doi.org/10.1016/j.ejim.2020.04.037.

14. Gan R, Rosoman NP, Henshaw DJE, Noble EP, Georgius P, Sommerfeld N. COVID-19 as a viral functional ACE2 deficiency disorder with ACE2 related multi-organ disease. Med Hypotheses. 2020;144: 110024. https://doi.org/10.1016/j.mehy. 2020.110024

15. Sfera A, Osorio C, Jafri N, Diaz EL, Campo Maldonado JE. Intoxication with endogenous angiotensin II: A COVID-19 hypothesis. Front Immunol. 2020;11:1472. https://doi.org/10. 3389/fimmu.2020.01472.

16. Li G, He X, Zhang L, Ran Q, Wang J, Xiong A, et al. Assessing ACE2 expression patterns in lung tissues in the pathogenesis of COVID-19. J Autoimmun. 2020;112: 102463. https://doi.org/10. 1016/j.jaut.2020.102463.

17. Trump S, Lukassen S, Anker MS, Chua RL, Liebig J, Thurmann $\mathrm{L}$, et al. Hypertension delays viral clearance and exacerbates airway hyperinflammation in patients with COVID-19. Nat Biotechnol. 2020. https://doi.org/10.1038/s41587-020-00796-1.
18. Chua RL, Lukassen S, Trump S, Hennig BP, Wendisch D, Pott F, et al. COVID-19 severity correlates with airway epitheliumimmune cell interactions identified by single-cell analysis. Nat Biotechnol. 2020;38(8):970-9. https://doi.org/10.1038/ s41587-020-0602-4.

19. Ziegler CGK, Allon SJ, Nyquist SK, Mbano IM, Miao VN, Tzouanas CN, et al. SARS-CoV-2 Receptor ACE2 Is an interferon-stimulated gene in human airway epithelial cells and is detected in specific cell subsets across tissues. Cell, 2020;181(5):1016-1035 e19. https://doi.org/10.1016/j.cell.2020. 04.035 .

20. Taboada M, Caruezo V, Naveira A, Atanassoff PG. Corticosteroids and the hyper-inflammatory phase of the COVID-19 disease. J Clin Anesth. 2020;66: 109926. https://doi.org/10.1016/j.jclinane. 2020.109926.

21. Patel S, Rauf A, Khan H, Abu-Izneid T. Renin-angiotensinaldosterone (RAAS): The ubiquitous system for homeostasis and pathologies. Biomed Pharmacother. 2017;94:317-25. https://doi. org/10.1016/j.biopha.2017.07.091.

22. Ingraham NE, Barakat AG, Reilkoff R, Bezdicek T, Schacker $\mathrm{T}$, Chipman JG, et al. Understanding the renin-angiotensinaldosterone-SARS-CoV axis: a comprehensive review. Eur Respir J. 2020;56(1). https://doi.org/10.1183/13993003. 00912-2020.

23. Karnik SS, Unal H, Kemp JR, Tirupula KC, Eguchi S, Vanderheyden $\mathrm{PM}$, et al. International union of basic and clinical pharmacology. XCIX. angiotensin receptors: interpreters of pathophysiological angiotensinergic stimuli [corrected]. Pharmacol Rev. 2015;67(4):754 819. https://doi.org/10.1124/pr.114.010454.

24. Carey RM, Wang ZQ, Siragy HM. Role of the angiotensin type 2 receptor in the regulation of blood pressure and renal function. Hypertension. 2000;35(1 Pt 2):155-63. https://doi.org/10.1161/ 01.hyp.35.1.155.

25. Timmermans PB, Benfield P, Chiu AT, Herblin WF, Wong PC, Smith RD. Angiotensin II receptors and functional correlates. Am J Hypertens. 1992;5(12 Pt 2):221S-235S. https://doi.org/10. 1093/ajh/5.12.221s.

26. Dell'Italia LJ, Collawn JF, Ferrario CM. Multifunctional Role of Chymase in Acute and Chronic Tissue Injury and Remodeling. Circ Res. 2018;122(2):319-36. https://doi.org/10.1161/CIRCRESAHA. 117.310978.

27. Dell'Italia LJ, Meng QC, Balcells E, Wei CC, Palmer R, Hageman GR, et al. Compartmentalization of angiotensin II generation in the dog heart. Evidence for independent mechanisms in intravascular and interstitial spaces. J Clin Invest. 1997;100(2):253-8. https://doi.org/10.1172/JCI11 9529.

28. Wei CC, Tian B, Perry G, Meng QC, Chen YF, Oparil S, et al. Differential ANG II generation in plasma and tissue of mice with decreased expression of the ACE gene. Am J Physiol Heart Circ Physiol. 2002;282(6):H2254-8. https://doi.org/10.1152/ajpheart. 00191.2001.

29. Skov J, Persson F, Frokiaer J, Christiansen JS. Tissue ReninAngiotensin systems: a unifying hypothesis of metabolic disease. Front Endocrinol (Lausanne). 2014;5:23. https://doi.org/10.3389/ fendo.2014.00023.

30. Ellis B, Li XC, Miguel-Qin E, Gu V, Zhuo JL. Evidence for a functional intracellular angiotensin system in the proximal tubule of the kidney. Am J Physiol Regul Integr Comp Physiol. 2012;302(5):R494-509. https://doi.org/10.1152/ajpregu.00487. 2011.

31. Navar LG, Mitchell KD, Harrison-Bernard LM, Kobori H, Nishiyama A. Review: Intrarenal angiotensin II levels in normal and hypertensive states. J Renin Angiotensin Aldosterone Syst. 2001;2(1_suppl):S176-S184. https://doi.org/10.1177/ 14703203010020013001. 
32. Nishiyama A, Kobori H. Independent regulation of renin-angiotensin-aldosterone system in the kidney. Clin Exp Nephrol. 2018;22(6):1231-9. https://doi.org/10.1007/s10157-018-1567-1.

33. Clarke NE, Turner AJ. Angiotensin-converting enzyme 2: the first decade. Int J Hypertens. 2012;2012: 307315. https://doi.org/ $10.1155 / 2012 / 307315$.

34. Garvin MR, Alvarez C, Miller JI, Prates ET, Walker AM, Amos BK, et al. A mechanistic model and therapeutic interventions for COVID-19 involving a RAS-mediated bradykinin storm. Elife. 2020;9. https://doi.org/10.7554/eLife.59177.

35. Wei CC, Hase N, Inoue Y, Bradley EW, Yahiro E, Li M, et al. Mast cell chymase limits the cardiac efficacy of Ang I-converting enzyme inhibitor therapy in rodents. J Clin Invest. 2010;120(4):1229-39. https://doi.org/10.1172/JCI39345.

36. Zhang H, Baker A. Recombinant human ACE2: acing out angiotensin II in ARDS therapy. Crit Care. 2017;21(1):305. https://doi. org/10.1186/s13054-017-1882-z.

37. Zhang R, Pan Y, Fanelli V, Wu S, Luo AA, Islam D, et al. Mechanical stress and the induction of lung fibrosis via the midkine signaling pathway. Am J Respir Crit Care Med. 2015;192(3):315-23. https://doi.org/10.1164/rccm. 201412-2326OC.

38. Adamzik M, Frey U, Sixt S, Knemeyer L, Beiderlinden M, Peters $\mathrm{J}$, et al. ACE I/D but not AGT (-6)A/G polymorphism is a risk factor for mortality in ARDS. Eur Respir J. 2007;29(3):482-8. https://doi.org/10.1183/09031936.00046106.

39. Zou Z, Yan Y, Shu Y, Gao R, Sun Y, Li X, et al. Angiotensin-converting enzyme 2 protects from lethal avian influenza A H5N1 infections. Nat Commun. 2014;5:3594. https://doi.org/10.1038/ ncomms4594.

40. Imai Y, Kuba K, Rao S, Huan Y, Guo F, Guan B, et al. Angiotensinconverting enzyme 2 protects from severe acute lung failure. Nature. 2005;436(7047):112-6. https://doi.org/10.1038/nature03712.

41. Wosten-van Asperen RM, Lutter R, Specht PA, Moll GN, van Woensel JB, van der Loos CM, et al. Acute respiratory distress syndrome leads to reduced ratio of ACE/ACE2 activities and is prevented by angiotensin-(1-7) or an angiotensin II receptor antagonist. J Pathol. 2011;225(4):618-27. https://doi.org/10.1002/path.2987.

42. Werner C, Baumhakel M, Teo KK, Schmieder R, Mann J, Unger T, et al. RAS blockade with ARB and ACE inhibitors: current perspective on rationale and patient selection. Clin Res Cardiol. 2008;97(7):418-31. https://doi.org/10.1007/s00392-008-0668-3.

43. Epelman S, Tang WH, Chen SY, Van Lente F, Francis GS, Sen $\mathrm{S}$. Detection of soluble angiotensin-converting enzyme 2 in heart failure: insights into the endogenous counter-regulatory pathway of the renin-angiotensin-aldosterone system. J Am Coll Cardiol. 2008;52(9):750-4. https://doi.org/10.1016/j.jacc.2008.02.088.

44. Ramchand J, Patel SK, Srivastava PM, Farouque O, Burrell LM. Elevated plasma angiotensin converting enzyme 2 activity is an independent predictor of major adverse cardiac events in patients with obstructive coronary artery disease. PLoS ONE. 2018;13(6): e0198144. https://doi.org/10.1371/journal.pone. 0198144 .

45. Zannad F, McMurray JJ, Krum H, van Veldhuisen DJ, Swedberg $\mathrm{K}$, Shi $\mathrm{H}$, et al. Eplerenone in patients with systolic heart failure and mild symptoms. N Engl J Med. 2011;364(1):11-21. https:// doi.org/10.1056/NEJMoa1009492.

46. Pitt B, Zannad F, Remme WJ, Cody R, Castaigne A, Perez A, et al. The effect of spironolactone on morbidity and mortality in patients with severe heart failure. Randomized Aldactone Evaluation Study Investigators. N Engl J Med. 1999;341(10):70917. https://doi.org/10.1056/NEJM199909023411001.

47. Crackower MA, Sarao R, Oudit GY, Yagil C, Kozieradzki I, Scanga SE, et al. Angiotensin-converting enzyme 2 is an essential regulator of heart function. Nature. 2002;417(6891):822-8. https://doi.org/10.1038/nature00786.
48. Alghamri MS, Weir NM, Anstadt MP, Elased KM, Gurley SB, Morris M. Enhanced angiotensin II-induced cardiac and aortic remodeling in ACE2 knockout mice. J Cardiovasc Pharmacol Ther. 2013;18(2):138-51. https://doi.org/10.1177/1074248412460124.

49. Yamamoto K, Ohishi M, Katsuya T, Ito N, Ikushima M, Kaibe $\mathrm{M}$, et al. Deletion of angiotensin-converting enzyme 2 accelerates pressure overload-induced cardiac dysfunction by increasing local angiotensin II. Hypertension. 2006;47(4):718-26. https:// doi.org/10.1161/01.HYP.0000205833.89478.5b.

50. Oliveira AC, Melo MB, Motta-Santos D, Peluso AA, Souza-Neto F, da Silva RF, et al. Genetic deletion of the alamandine receptor MRGD leads to dilated cardiomyopathy in mice. Am J Physiol Heart Circ Physiol. 2019;316(1):H123-33. https://doi.org/10. 1152/ajpheart.00075.2018.

51. Mizuiri S, Ohashi Y. ACE and ACE2 in kidney disease. World J Nephrol. 2015;4(1):74-82. https://doi.org/10.5527/wjn.v4.i1.74.

52. Santos RA, Ferreira AJ, Verano-Braga T, Bader M. Angiotensinconverting enzyme 2 , angiotensin-(1-7) and Mas: new players of the renin-angiotensin system. J Endocrinol. 2013;216(2):R1-17. https://doi.org/10.1530/JOE-12-0341.

53. Wakahara S, Konoshita T, Mizuno S, Motomura M, Aoyama C, Makino Y, et al. Synergistic expression of angiotensin-converting enzyme (ACE) and ACE2 in human renal tissue and confounding effects of hypertension on the ACE to ACE2 ratio. Endocrinology. 2007;148(5):2453-7. https://doi.org/10.1210/en.2006-1287.

54. Pinheiro SVB, Ferreira AJ, Kitten GT, da Silveira KD, da Silva DA, Santos SHS, et al. Genetic deletion of the angiotensin-(1-7) receptor Mas leads to glomerular hyperfiltration and microalbuminuria. Kidney Int. 2009;75(11):1184-93. https://doi.org/10. 1038/ki.2009.61.

55. Zhong J, Guo D, Chen CB, Wang W, Schuster M, Loibner H, et al. Prevention of angiotensin II-mediated renal oxidative stress, inflammation, and fibrosis by angiotensin-converting enzyme 2. Hypertension. 2011;57(2):314-22. https://doi.org/10.1161/ HYPERTENSIONAHA.110.164244.

56. Jin HY, Chen LJ, Zhang ZZ, Xu YL, Song B, Xu R, et al. Deletion of angiotensin-converting enzyme 2 exacerbates renal inflammation and injury in apolipoprotein E-deficient mice through modulation of the nephrin and TNF-alpha-TNFRSF1A signaling. J Transl Med. 2015;13:255. https://doi.org/10.1186/ s12967-015-0616-8.

57. Batlle D, Jose Soler M, Ye M. ACE2 and diabetes: ACE of ACEs? Diabetes. 2010;59(12):2994-6. https://doi.org/10.2337/ db10-1205.

58. Carlsson PO, Berne C, Jansson L. Angiotensin II and the endocrine pancreas: effects on islet blood flow and insulin secretion in rats. Diabetologia. 1998;41(2):127-33. https://doi.org/10.1007/ s001250050880.

59. Bindom SM, Lazartigues E. The sweeter side of ACE2: physiological evidence for a role in diabetes. Mol Cell Endocrinol. 2009;302(2):193-202. https://doi.org/10.1016/j.mce.2008.09.020.

60. Fliser D, Schaefer F, Schmid D, Veldhuis JD, Ritz E. Angiotensin II affects basal, pulsatile, and glucose-stimulated insulin secretion in humans. Hypertension. 1997;30(5):115661. https://doi.org/10.1161/01.hyp.30.5.1156.

61. Lau T, Carlsson PO, Leung PS. Evidence for a local angiotensin-generating system and dose-dependent inhibition of glucose-stimulated insulin release by angiotensin II in isolated pancreatic islets. Diabetologia. 2004;47(2):240-8. https://doi. org/10.1007/s00125-003-1295-1.

62. Niu MJ, Yang JK, Lin SS, Ji XJ, Guo LM. Loss of angiotensinconverting enzyme 2 leads to impaired glucose homeostasis in mice. Endocrine. 2008;34(1-3):56-61. https://doi.org/10.1007/ s12020-008-9110-x.

63. Santos SH, Fernandes LR, Mario EG, Ferreira AV, Porto LC, Alvarez-Leite JI, et al. Mas deficiency in FVB/N mice produces 
marked changes in lipid and glycemic metabolism. Diabetes. 2008;57(2):340-7. https://doi.org/10.2337/db07-0953.

64. Bindom SM, Hans CP, Xia H, Boulares AH, Lazartigues E. Angiotensin I-converting enzyme type 2 (ACE2) gene therapy improves glycemic control in diabetic mice. Diabetes. 2010;59(10):2540-8. https://doi.org/10.2337/db09-0782.

65. Yuan L, Li Y, Li G, Song Y, Gong X. Ang(1-7) treatment attenuates beta-cell dysfunction by improving pancreatic microcirculation in a rat model of Type 2 diabetes. J Endocrinol Invest. 2013;36(11):931-7. https://doi.org/10.3275/ 8951.

66. Arroja MM, Reid E, McCabe C. Therapeutic potential of the renin angiotensin system in ischaemic stroke. Exp Transl Stroke Med. 2016;8:8. https://doi.org/10.1186/s13231-016-0022-1.

67. Walther T, Olah L, Harms C, Maul B, Bader M, Hortnagl H, et al. Ischemic injury in experimental stroke depends on angiotensin II. FASEB J. 2002;16(2):169-76. https://doi.org/10.1096/fj.010601 com.

68. Wakayama K, Shimamura M, Suzuki JI, Watanabe R, Koriyama H, Akazawa H, et al. Angiotensin II Peptide Vaccine Protects Ischemic Brain Through Reducing Oxidative Stress. Stroke. 2017;48(5):1362_ 8. https://doi.org/10.1161/STROKEAHA.116.016269.

69. Inaba S, Iwai M, Tomono Y, Senba I, Furuno M, Kanno H, et al. Exaggeration of focal cerebral ischemia in transgenic mice carrying human Renin and human angiotensinogen genes. Stroke. 2009;40(2):597-603. https://doi.org/10.1161/STROKEAHA. 108.519801.

70. Bennion DM, Haltigan E, Regenhardt RW, Steckelings UM, Sumners C. Neuroprotective mechanisms of the ACE2-angiotensin-(1-7)-Mas axis in stroke. Curr Hypertens Rep. 2015;17(2):3. https://doi.org/10.1007/s11906-014-0512-2.

71. Lu J, Jiang T, Wu L, Gao L, Wang Y, Zhou F, et al. The expression of angiotensin-converting enzyme 2-angiotensin-(1-7)-Mas receptor axis are upregulated after acute cerebral ischemic stroke in rats. Neuropeptides. 2013;47(5):289-95. https://doi.org/10. 1016/j.npep.2013.09.002.

72. Mecca AP, Regenhardt RW, O'Connor TE, Joseph JP, Raizada MK, Katovich MJ, et al. Cerebroprotection by angiotensin-(1-7) in endothelin-1-induced ischaemic stroke. Exp Physiol. 2011;96(10):1084-96. https://doi.org/10.1113/expphysiol.2011.058578.

73. Garg M, Angus PW, Burrell LM, Herath C, Gibson PR, Lubel JS. Review article: the pathophysiological roles of the reninangiotensin system in the gastrointestinal tract. Aliment Pharmacol Ther. 2012;35(4):414-28. https://doi.org/10.1111/j.13652036.2011.04971.x.

74. Jin XH, Wang ZQ, Siragy HM, Guerrant RL, Carey RM. Regulation of jejunal sodium and water absorption by angiotensin subtype receptors. Am J Physiol. 1998;275(2):R515-23. https:// doi.org/10.1152/ajpregu.1998.275.2.R515.

75. Gomolak JR, Didion SP. Angiotensin II-induced endothelial dysfunction is temporally linked with increases in interleukin-6 and vascular macrophage accumulation. Front Physiol. 2014;5:396. https://doi.org/10.3389/fphys.2014.00396.

76. Shatanawi A, Romero MJ, Iddings JA, Chandra S, Umapathy NS, Verin AD, et al. Angiotensin II-induced vascular endothelial dysfunction through RhoA/Rho kinase/p38 mitogen-activated protein kinase/arginase pathway. Am J Physiol Cell Physiol. 2011;300(5):C1181-92. https://doi.org/10.1152/ajpcell.00328.2010.

77. Doughan AK, Harrison DG, Dikalov SI. Molecular mechanisms of angiotensin II-mediated mitochondrial dysfunction: linking mitochondrial oxidative damage and vascular endothelial dysfunction. Circ Res. 2008;102(4):488-96. https://doi.org/10.1161/ CIRCRESAHA.107.162800.

78. Pueyo ME, Michel JB. Angiotensin II receptors in endothelial cells. Gen Pharmacol. 1997;29(5):691-6. https://doi.org/10. 1016/s0306-3623(97)00021-9.
79. Szabo C, Pacher P, Zsengeller Z, Vaslin A, Komjati K, Benko R, et al. Angiotensin II-mediated endothelial dysfunction: role of poly(ADP-ribose) polymerase activation. Mol Med. 2004;10(16):28-35. https://doi.org/10.2119/2004-00001.szabo.

80. Gimbrone MA, Jr Garcia-Cardena G. Endothelial Cell Dysfunction and the Pathobiology of Atherosclerosis. Circ Res. 2016;118(4):620-36. https://doi.org/10.1161/CIRCRESAHA. 115.306301.

81. Romero A, San Hipolito-Luengo A, Villalobos LA, Vallejo S, Valencia I, Michalska P, et al. The angiotensin-(1-7)/Mas receptor axis protects from endothelial cell senescence via klotho and Nrf2 activation. Aging Cell. 2019,18(3):e12913. https://doi.org/ 10.1111/acel.12913.

82. Zhang YH, Zhang YH, Dong XF, Hao QQ, Zhou XM, Yu QT, et al. ACE2 and Ang-(1-7) protect endothelial cell function and prevent early atherosclerosis by inhibiting inflammatory response. Inflamm Res. 2015;64(3-4):253-60. https://doi.org/ 10.1007/s00011-015-0805-1.

83. Sampaio WO, Souza dos Santos RA, Faria-Silva R, da Mata Machado LT, Schiffrin EL, Touyz RM. Angiotensin-(1-7) through receptor Mas mediates endothelial nitric oxide synthase activation via Akt-dependent pathways. Hypertension. 2007;49(1):18592. https://doi.org/10.1161/01.HYP.0000251865.35728.2f

84. Fraga-Silva RA, Da Silva DG, Montecucco F, Mach F, Stergiopulos N, da Silva RF, et al. The angiotensin-converting enzyme 2/angiotensin-(1-7)/Mas receptor axis: a potential target for treating thrombotic diseases. Thromb Haemost. 2012;108(6):1089-96. https://doi.org/ 10.1160/TH12-06-0396.

85. Kucharewicz I, Pawlak R, Matys T, Pawlak D, Buczko W. Antithrombotic effect of captopril and losartan is mediated by angiotensin-(1-7). Hypertension. 2002;40(5):774-9. https://doi. org/10.1161/01.hyp.0000035396.27909.40.

86. Senchenkova EY, Russell J, Almeida-Paula LD, Harding JW, Granger DN. Angiotensin II-mediated microvascular thrombosis. Hypertension. 2010;56(6):1089-95. https://doi.org/10.1161/ HYPERTENSIONAHA.110.158220.

87. Satou R, Penrose H, Navar LG. Inflammation as a Regulator of the Renin-Angiotensin System and Blood Pressure. Curr Hypertens Rep. 2018;20(12):100. https://doi.org/10.1007/ s11906-018-0900-0.

88. Crowley SD, Rudemiller NP. Immunologic Effects of the ReninAngiotensin System. J Am Soc Nephrol. 2017;28(5):1350-61. https://doi.org/10.1681/ASN.2016101066.

89. Guo F, Chen XL, Wang F, Liang X, Sun YX, Wang YJ. Role of angiotensin II type 1 receptor in angiotensin II-induced cytokine production in macrophages. J Interferon Cytokine Res. 2011;31(4):351-61. https://doi.org/10.1089/jir.2010.0073.

90. Simoes e Silva AC, Silveira KD, Ferreira AJ, Teixeira MM. ACE2, angiotensin-(1-7) and Mas receptor axis in inflammation and fibrosis. Br J Pharmacol. 2013;169(3):47792. https://doi.org/10.1111/bph.12159.

91. Benigni A, Cassis P, Remuzzi G. Angiotensin II revisited: new roles in inflammation, immunology and aging. EMBO Mol Med. 2010;2(7):247-57. https://doi.org/10.1002/emmm.201000080.

92. Suzuki Y, Ruiz-Ortega M, Lorenzo O, Ruperez M, Esteban V, Egido J. Inflammation and angiotensin II. Int J Biochem Cell Biol. 2003;35(6):881-900. https://doi.org/10.1016/s13572725(02)00271-6.

93. Guan WJ, Ni ZY, Hu Y, Liang WH, Ou CQ, He JX, et al. Clinical Characteristics of Coronavirus Disease 2019 in China. N Engl J Med. 2020;382(18):1708-20. https://doi.org/10.1056/NEJMoa2002032.

94. Gupta A, Madhavan MV, Sehgal K, Nair N, Mahajan S, Sehrawat TS, et al. Extrapulmonary manifestations of COVID19. Nat Med. 2020;26(7):1017-32. https://doi.org/10.1038/ s41591-020-0968-3. 
95. Lei Y, Zhang J, Schiavon CR, He M, Chen L, Shen H, et al. SARS-CoV-2 Spike Protein Impairs Endothelial Function via Downregulation of ACE2. Circ Res. 2021. https://doi.org/10. 1161/CIRCRESAHA.121.318902.

96. Jin Y, Ji W, Yang H, Chen S, Zhang W, Duan G. Endothelial activation and dysfunction in COVID-19: from basic mechanisms to potential therapeutic approaches. Signal Transduct Target Ther. 2020;5(1):293. https://doi.org/10.1038/s41392-020-00454-7.

97. Gavriilaki E, Anyfanti P, Gavriilaki M, Lazaridis A, Douma S, Gkaliagkousi E. Endothelial Dysfunction in COVID-19: Lessons Learned from Coronaviruses. Curr Hypertens Rep. 2020;22(9):63. https://doi.org/10.1007/s11906-020-01078-6.

98. Janssen NAF, Grondman I, de Nooijer AH, Boahen CK, Koeken $\mathrm{V}$, Matzaraki V, et al. Dysregulated innate and adaptive immune responses discriminate disease severity in COVID-19. J Infect Dis. 2021. https://doi.org/10.1093/infdis/jiab065.

99. Fajgenbaum DC, June CH. Cytokine Storm. N Engl J Med. 2020;383(23):2255-73. https://doi.org/10.1056/NEJMra2026131.

100. Kaneko N, Kuo HH, Boucau J, Farmer JR, Allard-Chamard H, Mahajan VS, et al. Loss of Bcl-6-Expressing T Follicular Helper Cells and Germinal Centers in COVID-19. Cell. 2020;183(1):143157 e13. https://doi.org/10.1016/j.cell.2020.08.025.

101. Janiuk K, Jablonska E, Garley M. Significance of NETs Formation in COVID-19. Cells. 2021;10(1). https://doi.org/10.3390/ cells10010151.

102. Hirano T, Murakami M. COVID-19: A New Virus, but a Familiar Receptor and Cytokine Release Syndrome. Immunity. 2020;52(5):731-3. https://doi.org/10.1016/j.immuni.2020.04.003.

103. Okamoto H, Ichikawa N. The pivotal role of the angiotensin-IINF-kappaB axis in the development of COVID-19 pathophysiology. Hypertens Res. 2021;44(1):126-8. https://doi.org/10.1038/ s41440-020-00560-7.

104. Almyroudis NG, Grimm MJ, Davidson BA, Rohm M, Urban $\mathrm{CF}$, Segal BH. NETosis and NADPH oxidase: at the intersection of host defense, inflammation, and injury. Front Immunol. 2013;4:45. https://doi.org/10.3389/fimmu.2013.00045.

105. Hazan-Halevy I, Levy T, Wolak T, Lubarsky I, Levy R, Paran E. Stimulation of NADPH oxidase by angiotensin II in human neutrophils is mediated by ERK, p38 MAP-kinase and cytosolic phospholipase A2. J Hypertens. 2005;23(6):1183-90. https://doi. org/10.1097/01.hjh.0000170381.53955.68.

106. Huang C, Melnick A. Mechanisms of action of BCL6 during germinal center B cell development. Sci China Life Sci. 2015;58(12):1226-32. https://doi.org/10.1007/ s11427-015-4919-z.

107. Chen D, Zang YH, Qiu Y, Zhang F, Chen AD, Wang JJ, et al. BCL6 Attenuates Proliferation and Oxidative Stress of Vascular Smooth Muscle Cells in Hypertension. Oxid Med Cell Longev. 2019;2019:5018410. https://doi.org/10.1155/2019/5018410.

108. Chen D, Xiong XQ, Zang YH, Tong Y, Zhou B, Chen Q, et al. BCL6 attenuates renal inflammation via negative regulation of NLRP3 transcription. Cell Death Dis. 2017;8(10): e3156. https:// doi.org/10.1038/cddis.2017.567.

109. Hui DS, Wong PC, Wang C. SARS: clinical features and diagnosis. Respirology. 2003;8(Suppl):S20-4. https://doi.org/10.1046/j. 1440-1843.2003.00520.x

110. Zhu Z, Lian X, Su X, Wu W, Marraro GA, Zeng Y. From SARS and MERS to COVID-19: a brief summary and comparison of severe acute respiratory infections caused by three highly pathogenic human coronaviruses. Respir Res. 2020;21(1):224. https:// doi.org/10.1186/s12931-020-01479-w.

111. Daly JL, Simonetti B, Klein K, Chen KE, Williamson MK, Anton-Plagaro C, et al. Neuropilin-1 is a host factor for SARSCoV-2 infection. Science. 2020;370(6518):861-5. https://doi. org/10.1126/science.abd3072.
112. Wei C, Wan L, Yan Q, Wang X, Zhang J, Yang X, et al. HDLscavenger receptor B type 1 facilitates SARS-CoV-2 entry. Nat Metab. 2020;2(12):1391-400. https://doi.org/10.1038/ s42255-020-00324-0.

113. Wang K, Chen W, Zhang Z, Deng Y, Lian JQ, Du P, et al. CD147-spike protein is a novel route for SARS-CoV-2 infection to host cells. Signal Transduct Target Ther. 2020;5(1):283. https://doi.org/10.1038/s41392-020-00426-X.

114. Wang Y, Wang E, Zhang Y, Madamsetty VS, Ji B, Radisky DC, et al. Neuropilin-1 maintains dimethylarginine dimethylaminohydrolase 1 expression in endothelial cells, and contributes to protection from angiotensin II-induced hypertension. FASEB J. 2019;33(1):494-500. https://doi.org/10.1096/fj.201800499R.

115. Pilon A, Martin G, Bultel-Brienne S, Junquero D, Delhon A, Fruchart JC, et al. Regulation of the scavenger receptor BI and the LDL receptor by activators of aldosterone production, angiotensin II and PMA, in the human NCI-H295R adrenocortical cell line. Biochim Biophys Acta. 2003;1631(3):218-28. https://doi. org/10.1016/s1388-1981(03)00020-9.

116. Yvan-Charvet L, Bobard A, Bossard P, Massiera F, Rousset X, Ailhaud G, et al. In vivo evidence for a role of adipose tissue SR-BI in the nutritional and hormonal regulation of adiposity and cholesterol homeostasis. Arterioscler Thromb Vasc Biol. 2007;27(6):1340-5. https://doi.org/10.1161/ATVBAHA.106. 136382.

117. Ru NY, Cui LB, Jiao B, Zhang L, Jiang S, Yu ZB. Glycosylated CD147 reduces myocardial collagen cross-linking in cardiac hypertrophy. J Cell Biochem. 2018;119(10):8022-34. https:// doi.org/10.1002/jcb.26713.

118. Su H, Li J, Chen T, Li N, Xiao J, Wang S, et al. Melatonin attenuates angiotensin II-induced cardiomyocyte hypertrophy through the CyPA/CD147 signaling pathway. Mol Cell Biochem. 2016;422(1-2):85-95. https://doi.org/10.1007/ s11010-016-2808-9.

119. Zipeto D, Palmeira JDF, Arganaraz GA, Arganaraz ER. ACE2/ ADAM17/TMPRSS2 Interplay May Be the Main Risk Factor for COVID-19. Front Immunol. 2020;11: 576745. https://doi.org/10. 3389/fimmu.2020.576745.

120. Patel VB, Clarke N, Wang Z, Fan D, Parajuli N, Basu R, et al. Angiotensin II induced proteolytic cleavage of myocardial ACE2 is mediated by TACE/ADAM-17: a positive feedback mechanism in the RAS. J Mol Cell Cardiol. 2014;66:167-76. https://doi.org/ 10.1016/j.yjmcc.2013.11.017.

121. Patel SK, Juno JA, Lee WS, Wragg KM, Hogarth PM, Kent SJ, et al. Plasma ACE2 activity is persistently elevated following SARS-CoV-2 infection: implications for COVID-19 pathogenesis and consequences. Eur Respir J. 2021. https://doi.org/10. 1183/13993003.03730-2020.

122. Lew RA, Warner FJ, Hanchapola I, Yarski MA, Ramchand J, Burrell LM, et al. Angiotensin-converting enzyme 2 catalytic activity in human plasma is masked by an endogenous inhibitor. Exp Physiol. 2008;93(5):685-93. https://doi.org/10.1113/ expphysiol.2007.040352.

123. Yeung ML, Teng JLL, Jia L, Zhang C, Huang C, Cai JP, et al. Soluble ACE2-mediated cell entry of SARS-CoV-2 via interaction with proteins related to the renin-angiotensin system. Cell. 2021. https://doi.org/10.1016/j.cell.2021.02.053.

124. Huang C, Wang Y, Li X, Ren L, Zhao J, Hu Y, et al. Clinical features of patients infected with 2019 novel coronavirus in Wuhan, China. Lancet. 2020;395(10223):497-506. https://doi. org/10.1016/S0140-6736(20)30183-5.

125. Wolff D, Nee S, Hickey NS, Marschollek M. Risk factors for Covid-19 severity and fatality: a structured literature review. Infection. 2021;49(1):15-28. https://doi.org/10.1007/ s15010-020-01509-1. 
126. Zhu L, She ZG, Cheng X, Qin JJ, Zhang XJ, Cai J et al. Association of Blood Glucose Control and Outcomes in Patients with COVID-19 and Pre-existing Type 2 Diabetes. Cell Metab. 2020;31(6):1068-1077 e3. https://doi.org/10.1016/j.cmet. 2020.04.021.

127. Hutchings N, Babalyan V, Baghdasaryan S, Qefoyan M, Sargsyants N, Aghajanova E, et al. Patients hospitalized with COVID-19 have low levels of 25-hydroxyvitamin D. Endocrine. 2021;71(2):267-9. https://doi.org/10.1007/s12020-020-02597-7.

128. Lakatta EG. The reality of getting old. Nat Rev Cardiol. 2018;15(9):499-500. https://doi.org/10.1038/s41569-018-0068-y.

129. Abadir PM. The frail renin-angiotensin system. Clin Geriatr Med. 2011;27(1):53-65. https://doi.org/10.1016/j.cger.2010.08.004.

130. Ferrario CM. Role of angiotensin II in cardiovascular disease therapeutic implications of more than a century of research. J Renin Angiotensin Aldosterone Syst. 2006;7(1):3-14. https://doi. org/10.3317/jraas.2006.003.

131. Ribeiro-Oliveira A, Jr Nogueira AI, Pereira RM, Boas WW, Dos Santos RA, Simoes e Silva AC. The renin-angiotensin system and diabetes: an update. Vasc Health Risk Manag. 2008;4(4):787-803.

132. Ramalingam L, Menikdiwela K, LeMieux M, Dufour JM, Kaur G, Kalupahana N, et al. The renin angiotensin system, oxidative stress and mitochondrial function in obesity and insulin resistance. Biochim Biophys Acta Mol Basis Dis. 2017;1863(5):110614. https://doi.org/10.1016/j.bbadis.2016.07.019.

133. Mishra JS, More AS, Gopalakrishnan K, Kumar S. Testosterone plays a permissive role in angiotensin II-induced hypertension and cardiac hypertrophy in male rats. Biol Reprod. 2019;100(1):139-48. https://doi.org/10.1093/biolre/ioy179.

134. Mishra JS, Hankins GD, Kumar S. Testosterone downregulates angiotensin II type-2 receptor via androgen receptormediated ERK1/2 MAP kinase pathway in rat aorta. J Renin Angiotensin Aldosterone Syst. 2016;17(4). https://doi.org/10. 1177/1470320316674875.

135. Dalpiaz PL, Lamas AZ, Caliman IF, Ribeiro RF Jr, Abreu GR, Moyses MR, et al. Sex Hormones Promote Opposite Effects on ACE and ACE2 Activity, Hypertrophy and Cardiac Contractility in Spontaneously Hypertensive Rats. PLoS ONE. 2015;10(5): e0127515. https://doi.org/10.1371/journal.pone.0127515.

136. Sullivan JC. Sex and the renin-angiotensin system: inequality between the sexes in response to RAS stimulation and inhibition. Am J Physiol Regul Integr Comp Physiol. 2008;294(4):R1220-6. https://doi.org/10.1152/ajpregu.00864.2007.

137. Andersen LB, Przybyl L, Haase N, von Versen-Hoynck F, Qadri F, Jorgensen JS, et al. Vitamin D depletion aggravates hypertension and target-organ damage. J Am Heart Assoc. 2015;4(2). https://doi.org/10.1161/JAHA.114.001417.

138. Li YC, Kong J, Wei M, Chen ZF, Liu SQ, Cao LP. 1,25 -Dihydroxyvitamin $\mathrm{D}(3)$ is a negative endocrine regulator of the renin-angiotensin system. J Clin Invest. 2002;110(2):229-38. https://doi.org/10.1172/JCI15219.

139. Cui C, Xu P, Li G, Qiao Y, Han W, Geng C, et al. Vitamin D receptor activation regulates microglia polarization and oxidative stress in spontaneously hypertensive rats and angiotensin II-exposed microglial cells: Role of renin-angiotensin system. Redox Biol. 2019;26: 101295. https://doi.org/10.1016/j.redox.2019.101295.

140. Xu J, Yang J, Chen J, Luo Q, Zhang Q, Zhang H. Vitamin D alleviates lipopolysaccharideinduced acute lung injury via regulation of the reninangiotensin system. Mol Med Rep. 2017;16(5):74328. https://doi.org/10.3892/mmr.2017.7546.

141. Roca-Ho, H, Riera M, Palau V, Pascual J, Soler MJ. Characterization of ACE and ACE2 Expression within Different Organs of the NOD Mouse. Int J Mol Sci, 2017;18.(3). https://doi.org/ 10.3390/ijms18030563.

142. Khoury EE, Knaney Y, Fokra A, Kinaneh S, Azzam Z, Heyman $\mathrm{SN}$, et al. Pulmonary, cardiac and renal distribution of ACE2, furin, TMPRSS2 and ADAM17 in rats with heart failure: Potential implication for COVID-19 disease. J Cell Mol Med. 2021. https://doi.org/10.1111/jcmm.16310.

143. Bunyavanich S, Do A, Vicencio A. Nasal Gene Expression of Angiotensin-Converting Enzyme 2 in Children and Adults. JAMA. 2020;323(23):2427-9. https://doi.org/10.1001/jama. 2020.8707

144. Wark PAB, Pathinayake PS, Kaiko G, Nichol K, Ali A, Chen $\mathrm{L}$, et al. ACE2 expression is elevated in airway epithelial cells from older and male healthy individuals but reduced in asthma. Respirology. 2021. https://doi.org/10.1111/resp.14003.

145. Chen, J, Jiang Q, Xia X, Liu K, Yu Z, Tao W, et al. Individual variation of the SARS-CoV-2 receptor ACE2 gene expression and regulation. Aging Cell. 2020;19(7). https://doi.org/10.1111/ acel.13168.

146. Emilsson V, Gudmundsson EF, Aspelund T, Jonsson BG, Gudjonsson A, Launer LJ, et al. ACE2 levels are altered in comorbidities linked to severe outcome in COVID-19. medRxiv. 2020. https://doi.org/10.1101/2020.06.04.20122044.

147. Brosnihan KB, Senanayake PS, Li P, Ferrario CM. Bi-directional actions of estrogen on the renin-angiotensin system. Braz J Med Biol Res. 1999;32(4):373-81. https://doi.org/10.1590/s0100879x1999000400001.

148. Sullivan JC, Bhatia K, Yamamoto T, Elmarakby AA. Angiotensin (1-7) receptor antagonism equalizes angiotensin II-induced hypertension in male and female spontaneously hypertensive rats. Hypertension. 2010;56(4):658-66. https://doi.org/10.1161/ HYPERTENSIONAHA.110.153668.

149. O'Donnell E, Floras JS, Harvey PJ. Estrogen status and the renin angiotensin aldosterone system. Am J Physiol Regul Integr Comp Physiol. 2014;307(5):R498-500. https://doi.org/10.1152/ajpregu. 00182.2014.

150. Mancia G, Rea F, Ludergnani M, Apolone G, Corrao G. ReninAngiotensin-Aldosterone System Blockers and the Risk of Covid-19. N Engl J Med. 2020;382(25):2431-40. https://doi. org/10.1056/NEJMoa2006923.

151. Mehra MR, Desai SS, Kuy S, Henry TD, Patel AN. Cardiovascular Disease, Drug Therapy, and Mortality in Covid-19. N Engl J Med. 2020;382(25): e102. https://doi.org/10.1056/NEJMoa2007621.

152. Flacco ME, Acuti Martellucci C, Bravi F, Parruti G, Cappadona R, Mascitelli A, et al. Treatment with ACE inhibitors or ARBs and risk of severe/lethal COVID-19: a meta-analysis. Heart. 2020;106(19):1519_ 1524. https://doi.org/10.1136/heartjnl-2020-317336.

153. Yokoyama Y, Aikawa T, Takagi H, Briasoulis A, Kuno T. Association of renin-angiotensin-aldosterone system inhibitors with mortality and testing positive of COVID-19: Meta-analysis. J Med Virol. 2021;93(4):2084-9. https://doi.org/10.1002/jmv.26588.

154. Salah HM, Calcaterra G, Mehta JL. Renin-Angiotensin System Blockade and Mortality in Patients With Hypertension and COVID-19 Infection. J Cardiovasc Pharmacol Ther. 2020;25(6):503-7. https://doi.org/10.1177/1074248420947628.

155. Ren L, Yu S, Xu W, Overton JL, Chiamvimonvat N, Thai PN. Lack of association of antihypertensive drugs with the risk and severity of COVID-19: A meta-analysis. J Cardiol. 2021;77(5):482-91. https://doi.org/10.1016/j.jjcc.2020.10.015.

156. Lee MMY, Docherty KF, Sattar N, Mehta N, Kalra A, Nowacki AS, et al. Renin-angiotensin system blockers, risk of SARSCoV-2 infection and outcomes fromCoViD-19: systematic review and meta-analysis. Eur Heart J Cardiovasc Pharmacother. 2020. https://doi.org/10.1093/ehjcvp/pvaa138.

157. An J, Wei R, Zhou H, Luong TQ, Gould MK, Mefford MT, et al. Angiotensin-Converting Enzyme Inhibitors or Angiotensin Receptor Blockers Use and COVID-19 Infection Among 824 650 Patients With Hypertension From a US Integrated Healthcare System. J Am Heart Assoc. 2021;10(3): e019669. https:// doi.org/10.1161/JAHA.120.019669. 
158. Lopes RD, Macedo AVS, de Barros ESPGM, Moll-Bernardes RJ, Dos Santos TM, Mazza L, et al. Effect of Discontinuing vs Continuing Angiotensin-Converting Enzyme Inhibitors and Angiotensin II Receptor Blockers on Days Alive and Out of the Hospital in Patients Admitted With COVID-19: A Randomized Clinical Trial. JAMA. 2021;325(3):254-264. https://doi.org/10. 1001/jama.2020.25864.

159. Semenzato L, Botton J, Drouin J, Baricault B, Vabre C, Cuenot F, et al. Antihypertensive Drugs and COVID-19 Risk: A Cohort Study of 2 Million Hypertensive Patients. Hypertension. 2021;77(3):83342. https://doi.org/10.1161/HYPERTENSIONAHA.120.16314.

160. Morales DR, Conover MM, You SC, Pratt N, Kostka K, DuarteSalles T, et al. Renin-angiotensin system blockers and susceptibility to COVID-19: an international, open science, cohort analysis. Lancet Digit Health. 2021;3(2):e98-114. https://doi. org/10.1016/S2589-7500(20)30289-2.

161. Becari C, Oliveira EB, Salgado MC. Alternative pathways for angiotensin II generation in the cardiovascular system. Braz J Med Biol Res. 2011;44(9):914-9. https://doi.org/10.1590/s0100879x2011007500093.

162. Motta Junior JDS, Miggiolaro A, Nagashima S, de Paula CBV, Baena CP, Scharfstein J, et al. Mast Cells in Alveolar Septa of COVID-19 Patients: A Pathogenic Pathway That May Link Interstitial Edema to Immunothrombosis. Front Immunol. 2020;11:574862. https://doi.org/10.3389/fimmu.2020.574862.

163. Cure E, Ilcol TB, Cumhur Cure M. Angiotensin II, III, and IV may be important in the progression of COVID-19. J Renin Angiotensin Aldosterone Syst. 2020;21(4):1470320320972019 . https://doi.org/10.1177/1470320320972019.

164. Numaguchi Y, Ishii M, Kubota R, Morita Y, Yamamoto K, Matsushita T, et al. Ablation of angiotensin IV receptor attenuates hypofibrinolysis via PAI-1 downregulation and reduces occlusive arterial thrombosis. Arterioscler Thromb Vasc Biol. 2009;29(12):2102-8. https://doi.org/10.1161/ATVBAHA.109. 195057.

165. Group, R.C., P. Horby, W.S. Lim, J.R. Emberson, M. Mafham, J.L. Bell, et al. Dexamethasone in Hospitalized Patients with Covid-19. N Engl J Med. 2021;384(8):693-704. https://doi.org/ 10.1056/NEJMoa2021436.

166. Ayari H, Legedz L, Cerutti C, Lantelme P, Feugier P, Gustin MP, et al. Mutual amplification of corticosteroids and angiotensin systems in human vascular smooth muscle cells and carotid atheroma. J Mol Med (Berl). 2014;92(11):1201-8. https://doi.org/ 10.1007/s00109-014-1193-7.

167. Fishel RS, Eisenberg S, Shai SY, Redden RA, Bernstein KE, Berk BC. Glucocorticoids induce angiotensin-converting enzyme expression in vascular smooth muscle. Hypertension. 1995;25(3):343-9. https://doi.org/10.1161/01.hyp.25.3.343.

168. Ullian ME. The role of corticosteriods in the regulation of vascular tone. Cardiovasc Res. 1999;41(1):55-64. https://doi.org/ 10.1016/s0008-6363(98)00230-2.

169. Santoro T, Azevedo CT, PMR ES, Martins MA, Carvalho VF. Glucocorticoids decrease the numbers and activation of mast cells by inducing the transactivation receptors of AGEs. $\mathrm{J}$ Leukoc Biol. 2019;105(1):131-142. https://doi.org/10.1002/JLB. 3A0917-364RR.

170. Borson DB, Gruenert DC. Glucocorticoids induce neutral endopeptidase in transformed human tracheal epithelial cells. Am J Physiol. 1991;260(2 Pt 1):L83-9. https://doi.org/10.1152/ajplung. 1991.260.2.L83.

171. Graf K, Schaper C, Grafe M, Fleck E, Kunkel G. Glucocorticoids and protein kinase $\mathrm{C}$ regulate neutral endopeptidase 24.11 in human vascular smooth muscle cells. Basic Res Cardiol. 1998;93(1):11-7. https://doi.org/10.1007/s003950050056.

172. Zhang Y, Adner M, Cardell LO. Glucocorticoids suppress transcriptional up-regulation of bradykinin receptors in a murine in vitro model of chronic airway inflammation. Clin Exp Allergy. 2005;35(4):531-8. https://doi.org/10.1111/j.1365-2222.2005. 02207.x.

173. Schmidlin F, Scherrer D, Landry Y, Gies JP. Glucocorticoids inhibit the bradykinin $\mathrm{B} 2$ receptor increase induced by interleukin-1beta in human bronchial smooth muscle cells. Eur J Pharmacol. 1998;354(1):R7-8. https://doi.org/10.1016/s00142999(98)00478-6.

174. Auphan N, DiDonato JA, Rosette C, Helmberg A, Karin M. Immunosuppression by glucocorticoids: inhibition of NF-kappa $\mathrm{B}$ activity through induction of I kappa B synthesis. Science. 1995;270(5234):286-90. https://doi.org/10.1126/science.270. 5234.286.

175. Chow JH, Khanna AK, Kethireddy S, Yamane D, Levine A, Jackson AM, et al. Aspirin use is associated with decreased mechanical ventilation, intensive care unit admission, and inhospital mortality in hospitalized patients with coronavirus disease 2019. Anesth Analg. 2021;132(4):930-41. https://doi.org/ 10.1213/ANE.0000000000005292.

176. Zhang F, Lu M, Wang H, Ren T. Aspirin attenuates angiotensin II-induced inflammation in bone marrow mesenchymal stem cells via the inhibition of ERK1/2 and NF-kappaB activation. Biomed Rep. 2013;1(6):930-4. https://doi.org/10.3892/br.2013.160.

177. Husain S, Andrews NP, Mulcahy D, Panza JA, Quyyumi AA. Aspirin improves endothelial dysfunction in atherosclerosis. Circulation. 1998;97(8):716-20. https://doi.org/10.1161/01.cir.97.8. 716.

178. Monobe H, Yamanari H, Nakamura K, Ohe T. Effects of lowdose aspirin on endothelial function in hypertensive patients. Clin Cardiol. 2001;24(11):705-9. https://doi.org/10.1002/clc. 4960241104.

179. Taubert D, Berkels R, Grosser N, Schroder H, Grundemann D, Schomig E. Aspirin induces nitric oxide release from vascular endothelium: a novel mechanism of action. Br J Pharmacol. 2004;143(1):159-65. https://doi.org/10.1038/sj.bjp.0705907.

180. Mitra S, Wang X, Khaidakov M, Ding Z, Ayyadevera S, Hearnsberger $\mathrm{E}$, et al. Aspirin downregulates angiotensin type 1 receptor transcription implications in capillary formation from endothelial cells. J Cardiovasc Pharmacol. 2012;60(2):187-92. https://doi.org/10.1097/FJC. 0b013e31825b61e2.

181. Wang X, Lu J, Khaidakov M, Mitra S, Ding Z, Raina S, et al. Aspirin suppresses cardiac fibroblast proliferation and collagen formation through downregulation of angiotensin type 1 receptor transcription. Toxicol Appl Pharmacol. 2012;259(3):346-54. https://doi.org/10.1016/j.taap.2012.01.013.

182. Gupta A, Madhavan MV, Poterucha TJ, DeFilippis EM, Hennessey JA, Redfors B, et al. Association between antecedent statin use and decreased mortality in hospitalized patients with COVID-19. Nat Commun. 2021;12(1):1325. https://doi.org/10.1038/s41467-021-21553-1.

183. Drapala A, Sikora M, Ufnal M. Statins, the renin-angiotensinaldosterone system and hypertension - a tale of another beneficial effect of statins. J Renin Angiotensin Aldosterone Syst. 2014;15(3):250-8. https://doi.org/10.1177/1470320314531058.

184. Li YH, Wang QX, Zhou JW, Chu XM, Man YL, Liu P, et al. Effects of rosuvastatin on expression of angiotensin-converting enzyme 2 after vascular balloon injury in rats. J Geriatr Cardiol. 2013;10(2):151-8. https://doi.org/10.3969/j.issn.1671-5411. 2013.02.009.

185. Crouse AB, Grimes T, Li P, Might M, Ovalle F, Shalev A. Metformin use is associated with reduced mortality in a diverse population with covid-19 and diabetes. Front Endocrinol (Lausanne). 2020;11: 600439. https://doi.org/10.3389/fendo.2020.600439.

186. Chen C, Kassan A, Castaneda D, Gabani M, Choi SK, Kassan M. Metformin prevents vascular damage in hypertension through the AMPK/ER stress pathway. Hypertens Res. 2019;42(7):960-9. https://doi.org/10.1038/s41440-019-0212-z. 
187. Bai J, Zhang N, Hua Y, Wang B, Ling L, Ferro A, et al. Metformin inhibits angiotensin II-induced differentiation of cardiac fibroblasts into myofibroblasts. PLoS ONE. 2013;8(9): e72120. https://doi.org/10.1371/journal.pone.0072120.

188. Duan Q, Song P, Ding Y, Zou MH. Activation of AMP-activated protein kinase by metformin ablates angiotensin II-induced endoplasmic reticulum stress and hypertension in mice in vivo. Br J Pharmacol. 2017;174(13):2140-51. https://doi.org/10.1111/bph. 13833.

189. Zoufaly A, Poglitsch M, Aberle JH, Hoepler W, Seitz T, Traugott $\mathrm{M}$, et al. Human recombinant soluble ACE2 in severe COVID19. Lancet Respir Med. 2020;8(11):1154-8. https://doi.org/10. 1016/S2213-2600(20)30418-5.

190. Kiseleva AA, Troisi EM, Hensley SE, Kohli RM, Epstein JA. SARS-CoV-2 spike protein binding selectively accelerates substrate-specific catalytic activity of ACE2. J Biochem. 2021. https://doi.org/10.1093/jb/mvab041.

191. Lu J, Sun PD. High affinity binding of SARS-CoV-2 spike protein enhances ACE2 carboxypeptidase activity. J Biol Chem. 2020;295(52):18579-88. https://doi.org/10.1074/jbc.RA120. 015303.

192. Kutz A, Conen A, Gregoriano C, Haubitz S, Koch D, Domenig $\mathrm{O}$, et al. Renin-angiotensin-aldosterone system peptide profiles in patients with COVID-19. Eur J Endocrinol. 2021;184(4):543-52. https://doi.org/10.1530/EJE-20-1445.

193. Liu Y, Yang Y, Zhang C, Huang F, Wang F, Yuan J, et al. Clinical and biochemical indexes from 2019-nCoV infected patients linked to viral loads and lung injury. Sci China Life Sci. 2020;63(3):364-74. https://doi.org/10.1007/s11427-020-1643-8.

194. Rieder M, Wirth L, Pollmeier L, Jeserich M, Goller I, Baldus N, et al. Serum ACE-2, angiotensin II, and aldosterone levels are unchanged in patients with COVID-19. Am J Hypertens. 2020. https://doi.org/10.1093/ajh/hpaa169.

195. Henry BM, Benoit S, Lippi G, Benoit J. Letter to the Editor Circulating plasma levels of angiotensin II and aldosterone in patients with coronavirus disease 2019 (COVID-19): A preliminary report. Prog Cardiovasc Dis. 2020;63(5):702-3. https://doi. org/10.1016/j.pcad.2020.07.006.

196. Henry BM, Benoit JL, Berger BA, Pulvino C, Lavie CJ, Lippi G, et al. Coronavirus disease 2019 is associated with low circulating plasma levels of angiotensin 1 and angiotensin 1,7. J Med Virol. 2021;93(2):678-80. https://doi.org/10.1002/jmv.26479.

Publisher's Note Springer Nature remains neutral with regard to jurisdictional claims in published maps and institutional affiliations. 